\title{
Journal of

\section{Irreversible Inhibition of Epidermal Growth Factor Receptor Activity by 3-Aminopropanamides}

Caterina Carmi, $^{\dagger}$ Elena Galvani, ${ }^{\ddagger}$ Federica Vacondio, ${ }^{\dagger}$ Silvia Rivara, $^{\dagger}$ Alessio Lodola, $^{\dagger}$ Simonetta Russo, $^{\dagger}$ Stefania Aiello, ${ }^{\S}$ Fabrizio Bordi, ${ }^{\dagger}$ Gabriele Costantino, ${ }^{\dagger}$ Andrea Cavazzoni, ${ }^{\ddagger}$ Roberta R. Alfieri, ${ }^{\ddagger}$ Andrea Ardizzoni, ${ }^{\prime \prime}$ Pier Giorgio Petronini, ${ }^{\ddagger}$ and Marco Mor* ${ }^{\dagger}$

${ }^{\dagger}$ Dipartimento Farmaceutico, Università degli Studi di Parma, V.le G.P. Usberti 27/A, I-43124 Parma, Italy

${ }^{\ddagger}$ Dipartimento di Medicina Sperimentale, Università degli Studi di Parma, Via Volturno 39, I-43125 Parma, Italy

${ }^{\S}$ Dipartimento di Scienze e Tecnologie Molecolari e Biomolecolari, Università degli Studi di Palermo, Via Archirafi 32, I-90123 Palermo, Italy

"Oncologia Medica, Azienda Ospedaliero-Universitaria di Parma, V.le Gramsci 14, I-43125 Parma, Italy

Supporting Information

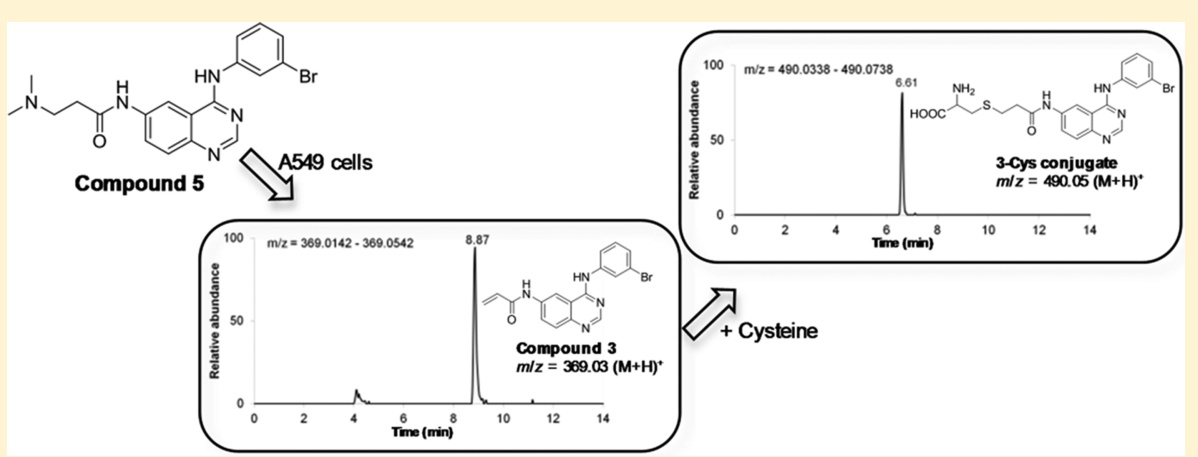

ABSTRACT: Irreversible epidermal growth factor receptor (EGFR) inhibitors contain a reactive warhead which covalently interacts with a conserved cysteine residue in the kinase domain. The acrylamide fragment, a commonly employed warhead, effectively alkylates Cys797 of EGFR, but its reactivity can cause rapid metabolic deactivation or nonspecific reactions with offtargets. We describe here a new series of irreversible inhibitors containing a 3-aminopropanamide linked in position 6 to 4 anilinoquinazoline or 4-anilinoquinoline-3-carbonitrile driving portions. Some of these compounds proved to be as efficient as their acrylamide analogues in inhibiting EGFR-TK (TK = tyrosine kinase) autophosphorylation in A549 lung cancer cells. Moreover, several 3-aminopropanamides suppressed proliferation of gefitinib-resistant H1975 cells, harboring the T790M mutation in EGFR, at significantly lower concentrations than did gefitinib. A prototypical compound, $\mathrm{N}$-(4-(3bromoanilino)quinazolin-6-yl)-3-(dimethylamino)propanamide (5), did not show covalent binding to cell-free EGFR-TK in a fluorescence assay, while it underwent selective activation in the intracellular environment, releasing an acrylamide derivative which can react with thiol groups.

\section{INTRODUCTION}

The epidermal growth factor receptor (EGFR, erbB1) is a member of the erbB family of receptor tyrosine kinases (RTKs), also including erbB2/HER2, erbB3/HER3, and erbB4/HER4. ${ }^{1,2}$ Upon ligand binding, EGFR forms homo- or heterodimers with other members of the erbB family and undergoes autophosphorylation of specific tyrosine residues in its intracellular domain. This event activates a series of downstream signals and regulates biological processes such as cell proliferation, apoptosis, angiogenesis, and differentiation., ${ }^{3,4}$ Deregulation of EGFR signaling has been observed in many human cancers, including lung, head and neck, colorectal, ovarian, breast, and bladder cancers, 5,6 and it has been associated with more aggressive disease and poorer clinical outcome. ${ }^{7}$ In this light, inhibitors targeting the EGFR have been extensively investigated and employed as antitumor agents.

The EGFR inhibitors $\mathbf{1}^{8}$ (gefitinib, Figure 1) and 4(3-ethynylanilino)-6,7-bis (2-methoxyethoxy)quinazoline ${ }^{9}$ (erlotinib, Figure 1) and the EGFR/erbB2 inhibitor $2^{10}$ (lapatinib, Figure 1) belong to the chemical class of 4-anilinoquinazolines, designed to bind the ATP binding pocket of the kinase domain of the target. Although $\mathbf{1}$ is effective in the treatment of nonsmall-cell lung cancer (NSCLC) in patients having activating mutations within the EGFR tyrosine kinase domain, ${ }^{11}$ accumulating clinical experience indicates that most patients develop resistance after repeated treatments. ${ }^{12}$ In half of NSCLC cases,

Received: November 8, 2011

Published: January 26, 2012 
<smiles>C#Cc1cccc(Nc2ncnc3cc(OCCOC)c(OCCOC)cc23)c1</smiles>

gefitinib (Iressa), 1<smiles>C=CC(=O)Nc1cc2c(Nc3ccc(F)c(Cl)c3)ncnc2cc1OCCCN1CCOCC1</smiles>

canertinib $(\mathrm{Cl}-1033)$ erlotinib (Tarceva)<smiles>CN(C)C/C=C/C(=O)Nc1cc2c(Nc3ccc(F)c(Cl)c3)c(C#N)cnc2cc1OC1CCOC1</smiles>

BIBW 2992 (Tovok) lapatinib (Tykerb), 2<smiles>CCOc1cc2ncc(C#N)c(Nc3ccc(OCc4ccccn4)c(Cl)c3)c2cc1NC(=O)/C=C/CN(C)C</smiles>

neratinib (HKI-272)

Figure 1. Chemical structures of reversible and irreversible EGFR inhibitors.

resistance was associated with the emergence of a single amino acid substitution in the catalytic domain of EGFR: conversion of the gatekeeper threonine 790 with methionine (T790M). ${ }^{12-15}$

Covalent alkylation of a cysteine residue (Cys797), positioned at the entrance of the ATP binding site, ${ }^{16,17}$ was the additional mechanism of second-generation irreversible EGFR inhibitors, which had been shown to overcome resistance to gefitinib. ${ }^{18-20}$ Several inhibitors of this class, such as $\mathrm{N}$-(4(3-chloro-4-fluoroanilino)-7-(3-morpholinopropoxy)quinazolin-6-yl)acrylamide ${ }^{21}$ (CI-1033, canertinib, Figure 1), $N$-(4-(3-chloro-4-fluoroanilino)-7-(tetrahydrofuran-3-yloxy)quinolin-6-yl)-4-(dimethylamino)but-2-enamide ${ }^{22}$ (BIBW2992, Figure 1), and N-(4-(3-chloro-4-(pyridin-2-ylmethoxy)anilino)-3-cyano-7-ethoxyquinolin-6-yl)-4-(dimethylamino)but-2enamide $^{23}$ (HKI-272, neratinib, Figure 1), have progressed to clinical investigation in patients that initially responded to 1 and subsequently relapsed. ${ }^{24}$ EGFR irreversible covalent inhibitors are characterized by a heterocyclic core structure (driving portion) carrying at a proper position an electrophilic functionality (warhead) that covalently interacts with the specific cysteine residue in the target protein. ${ }^{25-29}$ The ability of the warhead to covalently interact with nucleophiles is responsible for the advantages of EGFR irreversible inhibitors over conventional ATP-competitive ones: (i) overcoming secondary resistance, ${ }^{19}$ (ii) selectivity for erbB-family $\mathrm{TK}^{30}$ (iii) long-lasting effect. ${ }^{16}$ On the other hand, the intrinsic reactivity of the warhead is also associated with augmented metabolic degradation and toxicity, due to reactions with nontarget proteins. ${ }^{31,32}$ Systematic analysis of cysteine residues present in the nucleotide binding site of kinases had recently shown that combination of a driving portion and an electrophilic warhead could also be applied in a more general way to target different cysteines in different kinases. $^{33}$ To this aim, the availability of a panel of cysteinereactive groups with different reactivities could be beneficial for the development of new druglike inhibitors.

Recently, our group has reported a systematic exploration of the role and reactivity of warheads for EGFR-TK inhibition by introducing different cysteine-trap portions on a 4-anilinoquinazoline recognition scaffold. ${ }^{34}$ Compounds with different functional groups that were less reactive toward bionucleophiles (such as glutathione) than the reference acrylamide $3^{16}$ (PD168393, Table 1) proved efficient in irreversibly inhibiting EGFR autophosphorylation.

In our ongoing search for functional groups that are able to covalently interact with cysteine residues of EGFR, ${ }^{35-37}$ we focused on a new chemical entity containing a 3-aminopropanamide moiety. Aryl $\beta$-aminoethyl ketones (Mannich bases) have been described as irreversible inhibitors of enzymes having a crucial cysteine residue in the active site or at regulatory positions. ${ }^{38-40}$ These compounds possess a particular profile of reactivity, being nonreactive directly, but able to covalently modify their biological target after bioconversion via $\beta$-elimination to the corresponding $\alpha, \beta$-unsaturated carbonyl compound. Maresso and co-workers ${ }^{38}$ reported aryl $\beta$-aminoethyl ketones as irreversible inhibitors of the bacterial enzyme sortase, a target for the development of antibacterial therapeutics. They demonstrated through mass spectrometry and X-ray analysis that enzyme inhibition proceeds via a reactive olefin intermediate, generated in situ by amine elimination, which forms a covalent adduct with a specific cysteine residue within the protein active site. Aryl $\beta$-aminoethyl ketones have also been reported as inhibitors of intracellular kinases, such as Janus kinase 3 (Jak3), ${ }^{41}$ interleukin-2 inducible tyrosine kinase (ITK), ${ }^{42}$ and Bruton's tyrosine kinase (BTK) ${ }^{42}$ as well as weak EGFR tyrosine kinase inhibitors in enzymatic assay. ${ }^{43}$ Recently, $\beta$ aminolactones have also been described as novel anticancer agents, endowed with high oral bioavailability in rats. $\beta$ Aminolactone derivatives can undergo retro-Michael addition reaction to generate the parent $\alpha$-methylenelactones that interact with nucleophilic sites on biological macromolecules. ${ }^{44}$ In principle, masking the acrylamide warhead of irreversible inhibitors should reduce the risk of covalent interactions with offtargets, due to limited systemic exposure. Of course, this would result in a specific advantage only if the antiproliferative potency and efficacy of masked agents are equivalent or similar to those of corresponding compounds having a free acrylamide fragment.

In the present study, we describe the synthesis and biological evaluation of new EGFR-TK inhibitors containing a 3-aminopropanamide side chain linked to a 4-anilinoquinazoline (5-9, A-series, and 11-13, B-series, in Table 1) or 4anilinoquinoline-3-carbonitrile (15-17 and 19-21, C- and 
Table 1. EGFR Tyrosine Kinase and Autophosphorylation Inhibition in A549 Cells: Viability Inhibition of the H1975 Gefitinib-Resistant Cell Line

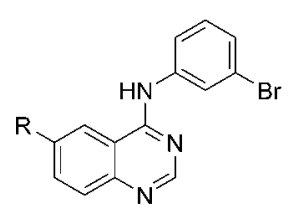

A

Compd Series

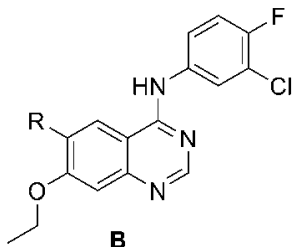

$\mathrm{R}$

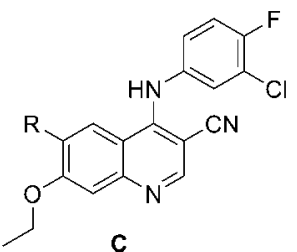

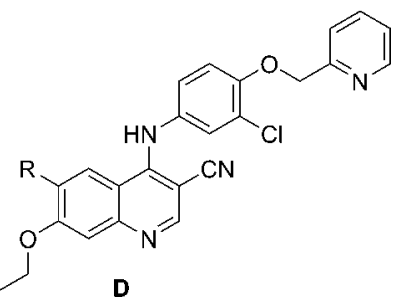

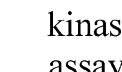

$$
\begin{array}{rr}
\begin{array}{l}
\text { kinase } \\
\text { assay }^{a}
\end{array} & \text { autophosphorylation } \\
(\text { A549) }
\end{array}
$$

1975 cell line $e^{c}$

\begin{tabular}{lccc}
$\mathrm{IC}_{50}(\mathrm{nM})$ & \multicolumn{2}{c}{$\begin{array}{c}\text { inhibition } \\
1 \mu \mathrm{M}\end{array}$} & $\mathrm{IC}_{50}(\mu \mathrm{M})$ \\
& $1 \mathrm{~h}$ & $8 \mathrm{~h}$ &
\end{tabular}

3

A<smiles>C=CC(=O)NC</smiles>

$1.69 \pm 0.16^{d}$

$98 \pm 1.8$

$86 \pm 0.4$

$0.61 \pm 0.05^{d}$

4

A

$\mathrm{H}_{2} \mathrm{~N}-$

n.d.

$91 \pm 5.9$

$0.0 \pm 0.1$

$19.5 \pm 2.46^{d}$

5
A<smiles>CNC(=O)CCN(C)C</smiles>

$0.28 \pm 0.07$

$97 \pm 1.4$

$89 \pm 1.0$

$3.69 \pm 1.10$

6

A<smiles>CNC(=O)CCN1CCCCC1</smiles>

$0.27 \pm 0.04$

$95 \pm 2.6$

$93 \pm 4.0$

$6.67 \pm 0.75$

7
A<smiles>CNC(=O)CCN1CCOCC1</smiles>

$0.51 \pm 0.06$

$98 \pm 1.8$

$91 \pm 5.4$

$>20$

8

9

10<smiles>CNC(=O)CCN1CCN(C)CC1</smiles>

$0.23 \pm 0.07$

A

A<smiles>CN(C)CCC(=O)N(C)C</smiles>

$17.4 \pm 1.62$<smiles>C=CC(=O)NC</smiles>

$0.18 \pm 0.04$

$96 \pm 4.0$

$99 \pm 0.6$

$1.62 \pm 0.45$

11

B<smiles>CNC(=O)CCN(C)C</smiles>

$0.27 \pm 0.05$

$98 \pm 1.1$

$100 \pm 0.3$

$2.21 \pm 0.69$

12

B<smiles>CNC(=O)CCN1CCCCC1</smiles>

$0.51 \pm 0.06$

$98 \pm 1.6$

$92 \pm 3.7$

$1.61 \pm 0.07$

13

B<smiles>CNC(=O)CCN1CCOCC1</smiles>

$0.29 \pm 0.06$

C<smiles>C=CC(=O)NC</smiles>

$1.46 \pm 0.37$

$92 \pm 4.4$

$97 \pm 2.3$

$97 \pm 0.4$

$2.11 \pm 0.63$

14

C 
Table 1. continued

\begin{tabular}{|c|c|c|c|c|c|c|}
\hline \multirow[t]{3}{*}{ Compd } & \multirow[t]{3}{*}{ Series } & \multirow[t]{3}{*}{$\mathrm{R}$} & $\begin{array}{l}\text { kinase } \\
\text { assay }^{a}\end{array}$ & \multicolumn{2}{|c|}{$\begin{array}{l}\text { autophosphorylation assay } \\
(\mathrm{A} 549)^{b}\end{array}$} & \multirow{3}{*}{$\begin{array}{c}\text { H1975 cell line }{ }^{c} \\
\mathrm{IC}_{50}(\mu \mathrm{M})\end{array}$} \\
\hline & & & \multirow[t]{2}{*}{$\mathrm{IC}_{50}(\mathrm{nM})$} & \multicolumn{2}{|c|}{$\begin{array}{c}\% \text { inhibition } \\
1 \mu \mathrm{M}\end{array}$} & \\
\hline & & & & $1 \mathrm{~h}$ & $8 \mathrm{~h}$ & \\
\hline 15 & $\mathrm{C}$ & & $0.68 \pm 0.11$ & $88 \pm 2.8$ & $67 \pm 8.6$ & $2.37 \pm 0.15$ \\
\hline 16 & $\mathrm{C}$ & & $2.21 \pm 0.37$ & $96 \pm 5.8$ & $82 \pm 3.6$ & $2.73 \pm 0.28$ \\
\hline 17 & $\mathrm{C}$ & & $2.02 \pm 0.44$ & $86 \pm 5.2$ & $48 \pm 7.4$ & $3.93 \pm 0.95$ \\
\hline 18 & $\mathrm{D}$ & & $50.7 \pm 1.33$ & $100 \pm 0.3$ & $83 \pm 7.9$ & $0.63 \pm 0.13$ \\
\hline 19 & $\mathrm{D}$ & & $12.5 \pm 0.88$ & $61 \pm 5.2$ & $59 \pm 11$ & $2.03 \pm 0.42$ \\
\hline 20 & $\mathrm{D}$ & & $24.8 \pm 3.88$ & $71 \pm 2.1$ & $58 \pm 3.2$ & $0.71 \pm 0.14$ \\
\hline 21 & $\mathrm{D}$ & & $37.5 \pm 8.99$ & $48 \pm 3.3$ & $39 \pm 9.5$ & $2.76 \pm 0.41$ \\
\hline
\end{tabular}

${ }^{a}$ Concentration to inhibit by $50 \%$ EGFR-wt tyrosine kinase activity. $\mathrm{IC}_{50}$ values were measured by the phosphorylation of a peptide substrate using time-resolved fluorometry (see the Experimental Section). Mean values of three independent experiments \pm SEM are reported. ${ }^{b}$ Inhibition of EGFR autophosphorylation was measured in A549 intact cells by Western blot analysis. The percent inhibition at $1 \mu \mathrm{M}$ concentration was measured immediately after and $8 \mathrm{~h}$ after removal of the compound from the medium ( $1 \mathrm{~h}$ of incubation). Mean values of at least two independent experiments \pm SEM are reported. ${ }^{c}$ Concentration to inhibit by $50 \%$ the proliferation of NSCLC H1975. The cell proliferation was determined by the MTT assay after $72 \mathrm{~h}$ of incubation with compounds $(0.1-20 \mu \mathrm{M})$. Mean values of three independent experiments \pm SEM are reported. ${ }^{d}$ Data from ref 34 .

D-series, respectively, in Table 1) driving portion. Reference acrylamide derivatives for each series were also prepared $(3,10$, 14, and 18, Table 1).

The new compounds were tested as EGFR tyrosine kinase inhibitors in enzyme-based and cell-based assays. Antiproliferative activity of the new compounds was also investigated in the gefitinib-resistant H1975 NSCLC cell line, harboring the T790M mutation. Moreover, for the most active agents, effects on mutated (T790M) EGFR autophosphorylation and on ErbB2 tyrosine kinase activity were evaluated. We hypothesized that the observed long-lasting effect on EGFR autophosphorylation was the result of an irreversible covalent interaction between the 3-aminopropanamide side chain and Cys797 within the active site of the enzyme. To evaluate this hypothesis, we performed a series of in vitro chemical stability assays, reactivity studies in the presence of thiol nucleophiles, and reactivity studies toward EGFR tyrosine kinase. Pharmacological data and reactivity study results were combined and evaluated to identify new irreversible EGFR inhibitors with lower intrinsic reactivity and optimized efficacy/toxicity profile compared to those of the other cysteine-reactive species described to date.

\section{CHEMISTRY}

Compounds of series A (5-9) of Table 1 were synthesized by coupling their precursor amines (4 or 26) with the proper carboxylic acid and substituting the terminal chlorine with various amines, as described in Scheme 1. The 6-amino-4(3-bromoanilino)quinazoline (4) was prepared in three steps from 5-nitroanthranilonitrile $(\mathbf{2 2})$ as previously described (Scheme 1). ${ }^{45,46}$ Condensation of 4 with 3-chloropropionyl chloride gave the 3-chloropropanamide intermediate 27a, which underwent substitution with the proper amine to obtain the secondary 3-aminopropanamides 5-9. Alternatively, 6-aminoquinazoline 4 was converted to its $N$-methyl analogue $26^{47}$ by carbamoylation with ethyl chloroformate in pyridine followed by reduction of the resulting carbamate 25 with sodium bis(2-methoxyethoxy)aluminum hydride (Red-Al). The ( $\mathrm{N}$ methylamino)quinazoline 26 thus generated was first condensed with 3-chloropropionyl chloride to $27 \mathbf{b}$ and then substituted with dimethylamine to obtain the tertiary 3aminopropanamide derivative 9 (Scheme 1).

4-(3-Chloro-4-fluoroanilino)-7-ethoxyquinazolino compounds of series B (10-13) of Table 1 were synthesized as described in Scheme 2. 6-Aminoquinazoline intermediate $34^{48}$ was obtained following a slightly modified procedure ${ }^{49}$ from 
Scheme 1. Synthesis of Compounds $4-9^{a}$

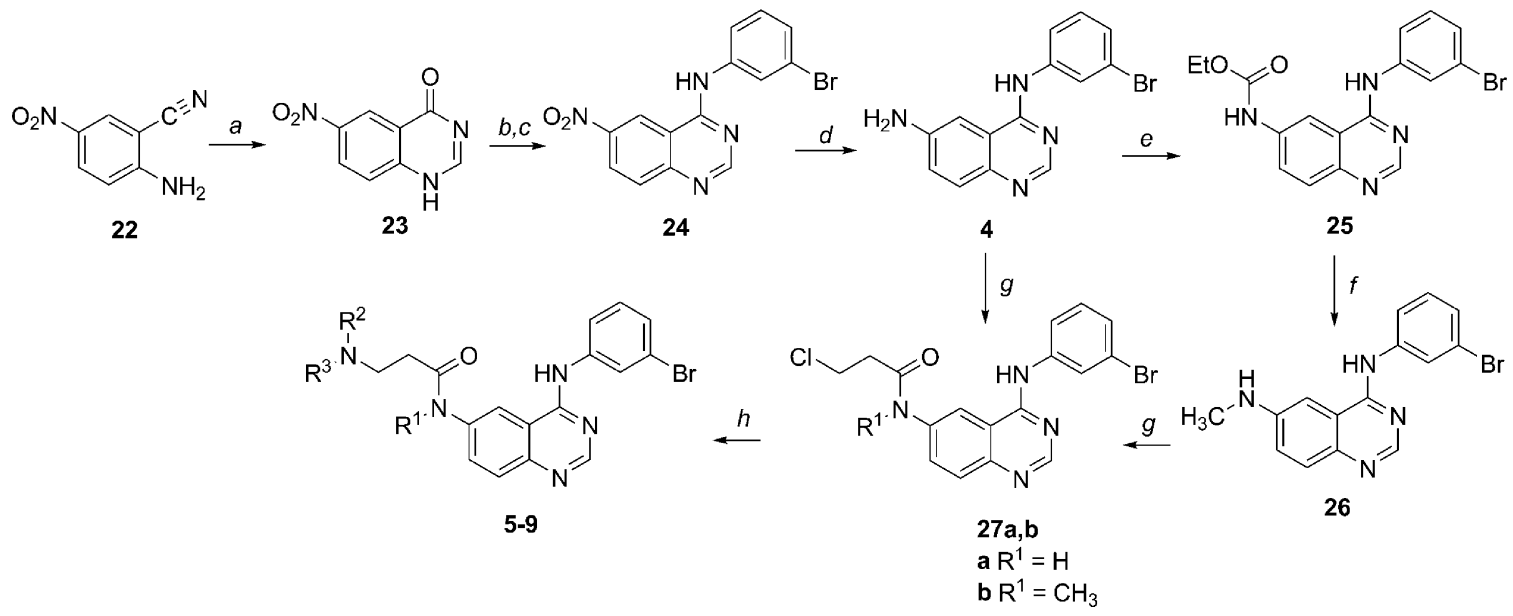

${ }^{a}$ Reagents and conditions: (a) $\mathrm{H}_{2} \mathrm{SO}_{4}$, formic acid, reflux; (b) $\mathrm{SOCl}_{2}$, dioxane, reflux; (c) 3-bromoaniline, $i$ - $\mathrm{PrOH}, 60{ }^{\circ} \mathrm{C}$; (d) Fe, AcOH, EtOH/ $\mathrm{H}_{2} \mathrm{O}$, reflux; (e) ClCOOEt, anhydrous pyridine, $0{ }^{\circ} \mathrm{C}$ to room temperature; (f) Red-Al, THF, room temperature; $(\mathrm{g}) \mathrm{ClCH}_{2} \mathrm{CH}_{2} \mathrm{COCl}, \mathrm{THF}$, $50{ }^{\circ} \mathrm{C}$; (h) $\mathrm{R}^{2} \mathrm{R}^{3} \mathrm{NH}, \mathrm{KI}$, absolute EtOH, reflux.

Scheme 2. Synthesis of Compounds $10-13^{a}$<smiles>Nc1cc(Cl)ccc1C(=O)O</smiles>

28<smiles></smiles>

29 30<smiles>CCOc1cc2nc(C)nc(Cl)c2cc1[N+](=O)[O-]</smiles><smiles>C=CC(=O)Nc1cc2c(Nc3ccc(F)c(Cl)c3)ncnc2cc1OCC</smiles><smiles>C1CC[Te]C1</smiles><smiles>[Y19]CCC(=O)Nc1cc2ncnc(Nc3ccc(F)c(Cl)c3)c2cc1OCC</smiles>

${ }^{a}$ Reagents and conditions: (a) formamidine acetate, 2-methoxyethanol, $130{ }^{\circ} \mathrm{C}$; (b) $\mathrm{H}_{2} \mathrm{SO}_{4}, \mathrm{HNO}_{3}, 100{ }^{\circ} \mathrm{C}$; (c) $\mathrm{NaOEt}$, anhydrous $\mathrm{EtOH}$, reflux; (d) $\mathrm{POCl}_{3}$, reflux; (e) 3-chloro-4-fluoroaniline, $i$ - $\mathrm{PrOH}$, reflux; (f) $\mathrm{Fe}, \mathrm{AcOH}, \mathrm{EtOH} / \mathrm{H}_{2} \mathrm{O}$, reflux; (g) acryloyl chloride, DIPEA, DMF, $0-50{ }^{\circ} \mathrm{C}$; (h) $\mathrm{ClCH}_{2} \mathrm{CH}_{2} \mathrm{COCl}, 50{ }^{\circ} \mathrm{C}$; (i) $\mathrm{R}^{2} \mathrm{R}^{3} \mathrm{NH}$, $\mathrm{KI}$, absolute EtOH, reflux.

4-chloroanthranilic acid (28). Briefly, cyclization of 28 with formamidine acetate followed by nitration gave a mixture of isomers from which pure $\mathbf{3 0}$ was obtained after recrystallization from acetic acid. The 7-chlorine group was substituted with sodium ethoxide, and the resulting 7-ethoxy derivative 31 was first chlorinated by heating in phosphorus oxychloride and then substituted with 3-chloro-4-fluoroaniline to obtain the intermediate 33. Reduction of the nitro group of 33 with iron and acetic acid gave the 6-aminoquinazoline 34 . The 6-acrylamide derivative 10 was then obtained from 34 with acryloyl chloride in the presence of $\mathrm{N}, \mathrm{N}$-diisopropylethylamine (DIPEA). Finally, 3-aminopropanamides 11-13 were synthesized from 34 by reaction with 3-chloropropionyl chloride to 35 and then substitution of the chlorine with the proper secondary amine (Scheme 2).

4-Anilinoquinoline-3-carbonitriles of series $\mathrm{C}$ and $\mathrm{D}$ (14-17 and 18-21, respectively) of Table 1 were synthesized as described in Scheme 3. The key N-(4-chloro-3-cyano-7-ethoxyquinolin-6-yl)acetamide intermediate (40) was synthesized in six steps from 2-amino-5-nitrophenol (36), as previously reported. ${ }^{50}$ The quinoline intermediate 40 was reacted with the proper aniline (to 41a and 41b) and deacetylated in aqueous hydrochloric acid to amines $42 a^{51}$ and $42 b{ }^{52}$ Aniline derivative 45 was synthesized by reaction of 4-amino-2-chlorophenol (44) and picolyl chloride in the presence of benzaldehyde as described in Scheme $3 .^{53}$ The acrylamides 14 and 18 were subsequently synthesized from amine precursors $42 a$ and $42 b$, respectively, with acryloyl chloride in the presence of a base (DIPEA). The 3-aminopropanamides 15-17 and 19-21 were synthesized in two steps from amines $\mathbf{4 2}$ by condensation with 3-chloropropionyl chloride and substitution with a secondary amine (Scheme 3).

\section{RESULTS AND DISCUSSION}

Kinase and Cellular Inhibitory Activities. Compounds 3-21 (Table 1) were evaluated in enzyme-based and cell-based assays for their ability to inhibit EGFR tyrosine kinase activity. Their inhibitor potency on human EGFR in a cell-free environment was measured on the phosphorylation of a peptide substrate using time-resolved fluorometry (see the Experimental Section). In these conditions, the reference compound 3 had an $\mathrm{IC}_{50}$ of $1.7 \mathrm{nM}^{34}$ Within the series of quinazoline derivatives with the same driving portion as 3 (series $\mathrm{A}$ in Table 1), substitution of the acrylamide warhead with a substituted 3-aminopropanamide (5-8) produced a generalized increase in 
Scheme 3. Synthesis of Compounds $14-21^{a}$<smiles>CCOc1cc(N)ccc1NC(C)=O</smiles><smiles>CCOc1cc2ncc(C)c(N[14CH3])c2cc1N</smiles><smiles>C=CC(=O)Nc1cc2c(N[Al])c(C#N)cnc2cc1OCC</smiles>

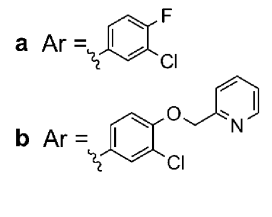<smiles>Nc1ccc(O)c(Cl)c1</smiles>

${ }^{a}$ Reagents and conditions: (a) $\mathrm{Ac} 2 \mathrm{O}, \mathrm{AcOH}, 60{ }^{\circ} \mathrm{C}$; (b) EtBr, DMF, $\mathrm{K}_{2} \mathrm{CO}_{3}, 60^{\circ} \mathrm{C}$; (c) $\mathrm{H}_{2}, \mathrm{Pd} / \mathrm{C}$, THF, room temperature; (d) toluene, $90{ }^{\circ} \mathrm{C}$; (e) Dowterm, $250{ }^{\circ} \mathrm{C}$; (f) $\mathrm{POCl}_{3}$, diglyme, $100{ }^{\circ} \mathrm{C}$; (g) 3-chloro-4-fluoroaniline or 45, pyridine hydrochloride, $i$-PrOH, reflux; (h) $\mathrm{HCl}$, reflux; (i) acryloyl chloride, DIPEA, DMF, $0-50{ }^{\circ} \mathrm{C}$; (j) $\mathrm{ClCH}_{2} \mathrm{CH}_{2} \mathrm{COCl}$, THF, $50{ }^{\circ} \mathrm{C}$; (k) $\mathrm{R}^{2} \mathrm{R}^{3} \mathrm{NH}, \mathrm{KI}$, absolute EtOH, reflux; (l) $\mathrm{PhCHO}_{2} \mathrm{~K}_{3}$, picolyl chloride hydrochloride, DMF, $50{ }^{\circ} \mathrm{C}$.

inhibitor potency, with $\mathrm{IC}_{50}$ values in the subnanomolar range. These values are likely to result from a complex inhibition mechanism, including reversible competition with ATP and covalent interaction with EGFR in different proportions for different compounds. We therefore consider these values as rough measures of the relative propensity to interact with the target. Methylation of the amide nitrogen of $\mathbf{5}$ to the tertiary amide 9 notably reduced EGFR-TK inhibition potency $\left(\mathrm{IC}_{50}=\right.$ $17 \mathrm{nM})$. B-series quinazoline compounds 10-13, carrying 4(4-fluoro-3-chloroanilino) and 7-ethoxy substituents, did not show significant changes in kinase inhibition potencies when the electrophilic warhead in $\mathbf{1 0}$ was replaced with 3(dimethylamino)propanamide in 11,3-piperidinopropanamide in 12, or 3-morpholinopropanamide in 13 , all compounds having subnanomolar $\mathrm{IC}_{50}$ values. Considering the two series of quinoline-3-carbonitriles $\mathrm{C}$ and $\mathrm{D}$, compounds 14-17 (C-series) were only slightly less potent in inhibiting EGFRTK compared to the parent B-series quinazoline derivatives, while compounds 17-21 (D-series), carrying a 3-chloro-4(3-fluorobenzyloxy)anilino substituent at position 4 similar to that of the EGFR/erbB2 inhibitor 2 (Figure 1), were up to 60fold less potent than the A- and B-series quinazolines. In view of the similarity between the D-series compounds (Table 1) and the EGFR/erbB2 inhibitor 2, the effect of 19 and 20 was also evaluated on erbB2-TK. Compound 2 is a slowly reversible, noncovalent inhibitor of tyrosine kinase that binds the enzyme in an inactive-like conformation, thus reducing the rate of inhibitor dissociation, enabling prolonged actions in biological systems. ${ }^{10}$ Results of enzyme-based assay for erbB2 inhibition by time-resolved fluorometry were compared to that of the 3-(dimethylamino)propanamide $\mathbf{5}$, belonging to the A-series of quinazoline compounds (Supporting Information, Table S2). As expected, while 5 did not inhibit erbB2 up to $10 \mu \mathrm{M}$ concentration, compounds 19 and 20 showed $\mathrm{IC}_{50}$ values for erbB2 tyrosine kinase inhibition in the submicromolar range $\left(\mathrm{IC}_{50}=0.97\right.$ and $0.98 \mu \mathrm{M}$, respectively). These data show that the 3 -aminopropanamide is well tolerated at both the EGFR and erbB2 binding sites of the quinazoline/ quinoline-3-carbonitrile driver portions.

The ability of the compounds to inhibit EGFR autophosphorylation was investigated in the A549 human lung cancer cell line by Western blotting. Percent inhibitions at $1 \mu \mathrm{M}$ concentration are reported in Table 1. Results were compared to those observed for the reference compounds 3 and 4, recognized as irreversible and reversible EGFR inhibitors, respectively. A549 cells, which express wild-type EGFR, were treated for $1 \mathrm{~h}$ with inhibitor and then washed with drug-free medium. The degree of EGFR autophosphorylation was measured either immediately after or $8 \mathrm{~h}$ after removal of the inhibitor. ${ }^{16}$ As previously reported, ${ }^{54} 80 \%$ or greater EGFR inhibition $8 \mathrm{~h}$ after removal of the inhibitor from the medium was considered a sign of irreversible inhibition. Within the A-series of 4anilinoquinazolines, the irreversible acrylamide 3 showed $86 \%$ inhibition after the $8 \mathrm{~h}$ washout. Substitution of the reactive acrylamide warhead with 3-(dimethylamino)propanamide in 5, 3-piperidinopropanamide in 6, or 3-morpholinopropanamide in 7 gave similar results on EGFR autophosphorylation, both immediately after and $8 \mathrm{~h}$ after washout, with inhibition of EGFR autophosphorylation over $95 \%$ and in the range of $89-93 \%$ at 1 and 8 h, respectively. The 4-methylpiperazine analogue 8 strongly inhibited EGFR autophosphorylation after $1 \mathrm{~h}$ (>99\% inhibition), while it showed a slight decrease in inhibitory activity $8 \mathrm{~h}$ after removal from the medium (79\% inhibition). The tertiary amide 9 poorly inhibited EGFR ( $47 \%$ inhibition at $1 \mathrm{~h}$ ) with only $10 \%$ residual inhibition $8 \mathrm{~h}$ after treatment, probably because of reduced affinity at the recognition site. As expected, the 6-amino derivative 4 completely inhibited EGFR activity after $1 \mathrm{~h}$ of treatment and did not show any inhibitory effect $8 \mathrm{~h}$ after its removal from the medium.

We further introduced the 3-aminopropanamido fragment on quinazoline or quinoline-3-carbonitrile scaffolds with 3-chloro4-fluoro substitution on the 4-aniline ring and a 7-ethoxy group on the heterocyclic nucleus (B- and C-series, Table 1) since previous work had suggested that this substitution pattern led 
to optimal activity. ${ }^{25,51}$ The acrylamide derivative 10, belonging to the B-series of quinazolines, completely inhibited EGFR autophosphorylation 1 and $8 \mathrm{~h}$ after treatment at $1 \mu \mathrm{M}$ concentration ( $96 \%$ and $99 \%$ inhibition, respectively). Substitution of the electrophilic warhead of $\mathbf{1 0}$ with a 3-aminopropanamide side chain led to compounds 11 (dimethylamino), 12 (piperidino), and 13 (morpholino), which gave EGFR percent inhibition 1 and $8 \mathrm{~h}$ after removal from the medium between $92 \%$ and $100 \%$. In the C-series of compounds, the acrylamide 14 proved efficient in inhibiting EGFR at $1 \mu \mathrm{M}$ concentration after $1 \mathrm{~h}$ of treatment $(92 \%$ inhibition), but produced only partial inhibition $8 \mathrm{~h}$ after washout (33\% inhibition). This unexpected behavior may be due to the reduced solubility of compound $\mathbf{1 4}$ in the reaction medium (data not shown). In fact, among 3-aminopropanamides $15-17$, only the piperidino derivative 16 gave complete and irreversible EGFR inhibition (92\% and $82 \%$ inhibition 1 and $8 \mathrm{~h}$ after removal from the medium, respectively), while dimethylamino (15) and morpholino (17) compounds inhibited EGFR at $1 \mathrm{~h}$, but produced only a partial, yet significant, irreversible inhibition $8 \mathrm{~h}$ after treatment, as demonstrated by $67 \%$ and $48 \%$ inhibition of autophosphorylation, respectively.

Partial inhibition of EGFR autophosphorylation in A459 cells was also shown by the other series of quinoline-3-carbonitrile derivatives (D-series, 19-21). In this series, the acrylamide 18 was quite effective as an irreversible inhibitor of EGFR (100\% and $83 \%$ inhibition 1 and $8 \mathrm{~h}$ after treatment, respectively), while 3-(dimethylamino)propanamide 19, 3-piperidinopropanamide 20, and 3-morpholinopropanamide 21 produced incomplete EGFR inhibition after $1 \mathrm{~h}$ of treatment at $1 \mu \mathrm{M}$ concentration (inhibitions between $48 \%$ and $71 \%$ ) with only partial inhibition $8 \mathrm{~h}$ after removal from the medium (19,59\% inhibition at $8 \mathrm{~h} ; 20,58 \%$ inhibition at $8 \mathrm{~h} ; 21,39 \%$ inhibition at $8 \mathrm{~h}$ ).

Activity on Gefitinib-Resistant H1975 Cells. Compounds 5-21 were evaluated for their ability to inhibit the growth of the gefitinib-resistant H1975 NSCLC cell line harboring the T790M mutation by MTT assay. Results were compared with those of the reference compounds 1,3 , and 4 in the same assay. As reported in Table 1, the 3-(dimethylamino)propanamide $\mathbf{5}$ showed the best antiproliferative activity on H1975 cells within the A-series of quinazoline compounds with an $\mathrm{IC}_{50}$ of $3.7 \mu \mathrm{M}$, being 2 times more potent than 1 ( $\mathrm{IC}_{50}$ of $8.3 \mu \mathrm{M})^{34}$ and 5-fold more active than $4\left(\mathrm{IC}_{50}\right.$ of $\left.19.5 \mu \mathrm{M}\right){ }^{34}$ Substitution of the dimethylamino group with a piperidine made compound 6 equally as potent as $1\left(\mathrm{IC}_{50}\right.$ of $\left.6.7 \mu \mathrm{M}\right)$, while 3-morpholinopropanamide 7, 3-(4-methylpiperazino)propanamide 8, and 3-(dimethylamino)- $\mathrm{N}$-methylpropanamide 9 gave $\mathrm{IC}_{50}$ values over $13 \mu \mathrm{M}$. B-series 3-aminoamides 11-13 proved 3-4 times more effective than 1 in inhibiting H1975 proliferation and showed $\mathrm{IC}_{50}$ values between 1.6 and $2.2 \mu \mathrm{M}$, in the same range as that of the corresponding irreversible acrylamide 10 ( $\mathrm{IC}_{50}$ of $\left.1.6 \mu \mathrm{M}\right)$. Compounds characterized by a quinoline-3-carbonitrile driving portion ( $\mathrm{C}$ - and $\mathrm{D}$-series) were more potent than 1 in inhibiting $\mathrm{H} 1975$ cell proliferation. In particular, 3-aminopropanamides 15-17 (C-series) showed $\mathrm{IC}_{50}$ values between 2.4 and $4.0 \mu \mathrm{M}$, comparable to that of the corresponding acrylamide derivative 14. Finally, D-series quinoline-3-carbonitriles 19-21 gave similar results, with the compounds displaying $\mathrm{IC}_{50}$ values in the low micromolar or submicromolar range. The 3-piperidinopropanamide derivative 20 proved to have the most potent antiproliferative effect on H1975 cells within all the series of 3-aminopropanamide derivatives $\left(\mathrm{IC}_{50}\right.$ of $\left.0.7 \mu \mathrm{M}\right), 11$ times more potent than 1 in the same test.

We further examined the ability of compounds $\mathbf{5}$ and $\mathbf{2 0}$ to inhibit EGFR autophosphorylation in the NSCLC cell line H1975 harboring the T790M mutation on EGFR. Results of Western blot analysis are shown in Figure 4. The compounds produced dose-dependent inhibition of EGFR autophosphorylation, indicating that the 3-aminopropanamide side chain had a positive effect on EGFR-T790M inhibition (compound $\mathbf{1}$ had marginal activity on EGFR in $\mathrm{H} 1975$ cells up to $10 \mu \mathrm{M}) .{ }^{34}$ In particular, quinazoline derivative 5 showed an $\mathrm{IC}_{50}$ of $0.07 \mu \mathrm{M}$, and the potent antiproliferative quinoline-3-carbonitrile derivative 20 had an $\mathrm{IC}_{50}$ of $0.15 \mu \mathrm{M}$. No correlation was found between enzyme activities and the ability of these compounds to inhibit the growth of the H1975 cell line nor between wildtype EGFR and T790M-mutated EGFR autophosphorylation inhibition. However, this was not an unexpected result, as factors other than EGFR-TK inhibiting potency (e.g., cell permeability of our compounds) may account for the results observed.

Reactivity Studies. Compound 5, carrying a 3(dimethylamino)propanamidic side chain at position 6 on a 4-(3-bromoanilino)quinazoline nucleus, was chosen as the prototype of the new series and tested for its chemical (buffered solutions at $\mathrm{pH} 7.4$ and 9.0) and biological $(80 \%(\mathrm{v} / \mathrm{v})$ rat plasma) stability, as well as for its reactivity against low molecular weight (LMW) thiol nucleophiles. Results were compared to those obtained for the acrylamide 3 (Tables 2 and 3 ).

Both compounds 3 and 5 were stable at $\mathrm{pH} 7.4$, with percentages of remaining compound over $97 \%$ after $24 \mathrm{~h}$ of incubation at $37{ }^{\circ} \mathrm{C}$ in buffer (Table 2). Under alkaline $\mathrm{pH}$ con-

Table 2. In Vitro Stability Studies on Compounds 3 and 5

\begin{tabular}{|c|c|c|}
\hline \multirow[b]{2}{*}{ conditions } & \multicolumn{2}{|c|}{$\begin{array}{l}\text { percentage of compd remaining } \\
\qquad(1 \mu \mathrm{M}, 24 \mathrm{~h})^{a}\end{array}$} \\
\hline & 3 & 5 \\
\hline pH 7.4 & $102.3 \pm 3.1$ & $97.5 \pm 0.1$ \\
\hline pH 9.0 & $105.2 \pm 3.7$ & $77.0 \pm 0.8$ \\
\hline $80 \%(\mathrm{v} / \mathrm{v})$ rat plasma & $21.8 \pm 7.4$ & $98.7 \pm 4.6$ \\
\hline
\end{tabular}

${ }^{a}$ Percentage of parent compound detected by LC-UV and LC-ESIMS after incubation for the indicated time at $37{ }^{\circ} \mathrm{C}$ (see the Experimental Section). Mean $\pm \mathrm{SD}, n=3$.

Table 3. In Vitro Reactivity Studies on Compounds 3 and 5

\begin{tabular}{lcc} 
& \multicolumn{2}{c}{ percentage of compd remaining $(1 \mu \mathrm{M}, 1 \mathrm{~h})^{a}$} \\
\cline { 2 - 3 } conditions & $\mathbf{3}$ & $\mathbf{5}$ \\
DTT & $100.0 \pm 2.3$ & $99.2 \pm 8.1$ \\
GSH & $63.8 \pm 1.9$ & $101.4 \pm 2.8$ \\
NAC & $85.6 \pm 3.1$ & $100.4 \pm 2.1$ \\
cysteamine & $20.1 \pm 0.4$ & $100.0 \pm 1.1$
\end{tabular}

${ }^{a}$ Percentage of parent compound detected by LC-UV and LC-ESIMS after incubation in the presence of LMW thiols $(2 \mathrm{mM})$ for the indicated time at $\mathrm{pH} 7.4,37^{\circ} \mathrm{C}$ (see the Experimental Section). Mean $\pm \mathrm{SD}, n=3$.

ditions ( $\mathrm{pH}$ 9.0), while 3 was stable over the entire incubation time, $77 \%$ of intact 3 -aminopropanamide 5 was recovered, with acrylamide 3 (19\%) and amine 4 (4\%) as the major degradation products (see the Supporting Information, Figure S1, for details). In the presence of rat plasma, compound $\mathbf{5}$ showed high stability, while only $22 \%$ of acrylamide 3 was detected after 
$24 \mathrm{~h}$ of incubation. The reactivity of compounds 3 and 5 against thiol nucleophiles was evaluated according to literature procedures. ${ }^{55,56}$ While for the acrylamide derivative 3 significant formation of conjugates was detected in the presence of cysteamine, glutathione (GSH), and $\mathrm{N}$-acetylcysteine (NAC) (Table 3 and Supporting Information, Figure S2), compound 5 gave no measurable adducts with thiol derivatives up to $24 \mathrm{~h}$ of incubation.

Intracellular concentrations of 5, 3, and 4 were measured by HPLC-ESI-MS in A549 lung cancer cells under the conditions of the EGFR autophosphorylation assay, i.e., immediately after or $8 \mathrm{~h}$ after incubation for $1 \mathrm{~h}$ with the compound at $1 \mu \mathrm{M}$ (see the Experimental Section and Supporting Information, Table S1). ${ }^{57}$ Both 4 and $\mathbf{5}$ were detected in the intracellular extracts after incubation $(0.105 \pm 0.010$ and $0.050 \pm$ $0.010 \mathrm{nmol} / \mathrm{mg}$ of protein, respectively), while their levels dropped below the limit of detection (LOD) of the LC-MS method when measured $8 \mathrm{~h}$ after incubation. Intracellular concentrations of 3 were below the limit of detection both 1 and $8 \mathrm{~h}$ after incubation. This result is probably due to the reactivity of the acrylamide group in $\mathbf{3}$, interacting covalently with cellular components.

The reactivity of $\mathbf{5}$ was also tested in the presence of purified EGFR-TK by a fluorescence-based assay for evaluation of irreversible kinase inhibition. ${ }^{58,59}$ Fluorescent molecules are very sensitive to solvent polarity and dipolar perturbation from their environments. ${ }^{60,61}$ Moreover, reversible interactions, ${ }^{62}$ such as solvation, hydrogen bonding, charge transfer, and redox, as well as irreversible interactions, ${ }^{3}$ such as Michael addition of thiols to electron-deficient alkenes, significantly influence the fluorescence spectra of fluorophores. In particular, quinazoline and quinoline fluorophores had been shown to significantly enhance fluorescence emission after covalent reaction with Cys797 of EGFR-TK. ${ }^{58}$ Thus, the 3-aminopropanamide 5 was added to a buffered solution containing EGFR-TK (see the Experimental Section and Figure 2A for details), samples were excited at $390 \mathrm{~nm}$, and fluorescence emission at $420 \mathrm{~nm}$ was monitored over time. The results were compared to those of the irreversible 3 and the reversible $N$-(4-(3-bromoanilino)quinazolin-6-yl)acetamide $^{64}$ (46) (Figure 2B). Upon addition of 3 to EGFR-TK, covalent bond formation with the cysteine sulfhydryl group resulted in a time-dependent saturable increase in emission intensity at $420 \mathrm{~nm}$, whereas a significantly lower fluorescence change was observed over $50 \mathrm{~min}$ when the reversible 6-acetyl compound 46 or the 3 -aminopropanamide 5 was added to EGFR-TK. This result suggests that $\mathbf{5}$ did not covalently react with EGFR under these experimental conditions, behaving more like the acetamide derivative than like the acrylamide one.

Finally, compounds $\mathbf{3}$ and $\mathbf{5}$ were tested for their reactivity in A549 cell lysate. The formation of conjugates with cysteine added in molar excess $(2 \mathrm{mM})$ was evaluated in cell lysate by LC-HRMS employing an LTQ-Orbitrap mass analyzer. ${ }^{56}$ Compound 3 quickly reacted with the thiol derivative to form the corresponding cysteine conjugate (data not shown). When compound $\mathbf{5}$ was added to the cell lysate containing cysteine, a peak corresponding to the acrylamide derivative 3 was detected after $1 \mathrm{~h}\left([\mathrm{M}+\mathrm{H}]^{+}=369.03, t_{\mathrm{R}}=8.87\right.$; Figure $\left.3 \mathrm{~A}\right)$, as well as a peak corresponding to the adduct of cysteine to the acrylamide fragment $\left([\mathrm{M}+\mathrm{H}]^{+}=490.05, t_{\mathrm{R}}=6.61 \mathrm{~min}\right.$; Figure $\left.3 \mathrm{~B}\right)$. After $1 \mathrm{~h}$ of incubation, $25.5 \%$ of the starting acrylamide 3 had been converted to the corresponding cysteine conjugate, compared to a $1.1 \%$ conversion observed for 5 . The concentration of

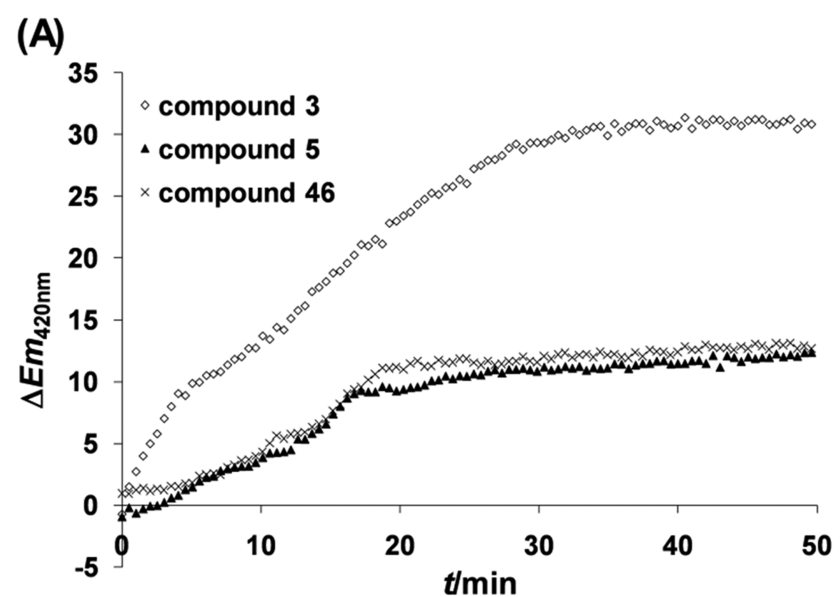

(B)

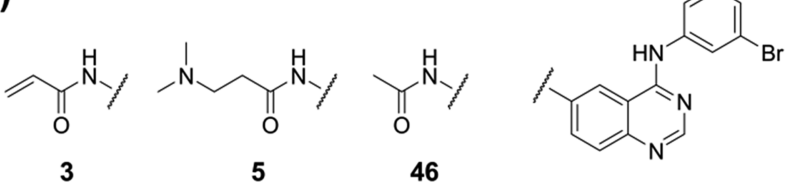

Figure 2. Fluorescence-based assay for irreversible kinase inhibition. (A) Compounds 3, 5, and $46(1 \mu \mathrm{M})$ were added to purified EGFRTK $(0.5 \mu \mathrm{M})$ in the presence of ATP $(1 \mathrm{mM})$, and fluorescence emission was monitored at $420 \mathrm{~nm}$ in real time over $50 \mathrm{~min}$ (excitation $390 \mathrm{~nm}) \cdot \Delta \mathrm{Em}_{420 \mathrm{~nm}}=\mathrm{Em}_{\text {compd+EGFR solution }}-\mathrm{Em}_{\text {compd solution }}$ - $\mathrm{Em}_{\mathrm{EGFR} \text { solution }}$ (B) Chemical structures of compounds 3, 5, and 46.
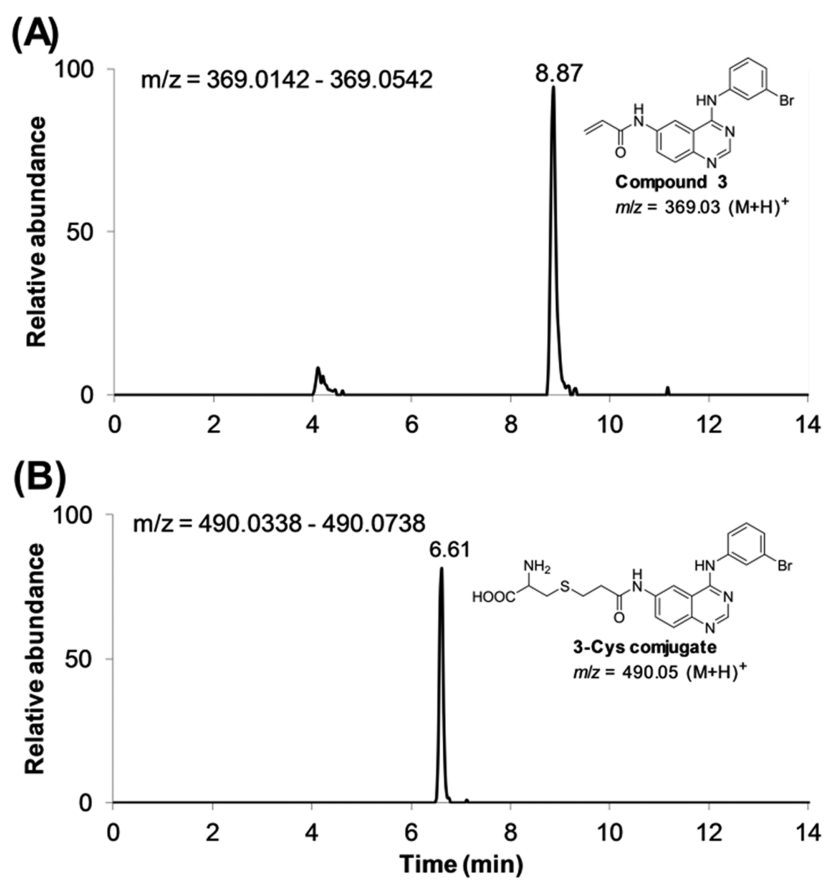

Figure 3. HPLC-HRMS extracted ion chromatograms of A549 cell lysate after $1 \mathrm{~h}$ of incubation in the presence of compound $5(10 \mu \mathrm{M})$ and cysteine $(2 \mathrm{mM}):(\mathrm{A})$ formed acrylamide derivative $(\mathrm{m} / z=$ 369.03, $\left.[\mathrm{M}+\mathrm{H}]^{+}, t_{\mathrm{R}}=8.81 \mathrm{~min}\right)$, (B) acrylamide-cysteine conjugate $\left(m / z=490.03,[\mathrm{M}+\mathrm{H}]^{+}, t_{\mathrm{R}}=6.61 \mathrm{~min}\right)$.

cysteine conjugate doubled for both $\mathbf{3}$ and $\mathbf{5}$ at the second time point $(t=4 \mathrm{~h})$, being $54.4 \%$ (3) and $2.0 \%$ (5) of the starting concentrations, respectively. The unique identity of the conjugate formed by compounds 3 and $\mathbf{5}$ with cysteine was further confirmed by high-resolution mass spectrometry (Supporting Information, Figure S4). On the other hand, the 


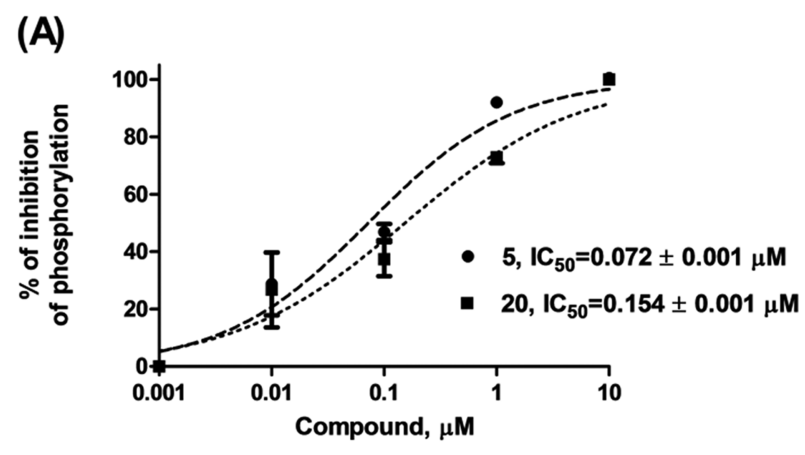

(B)

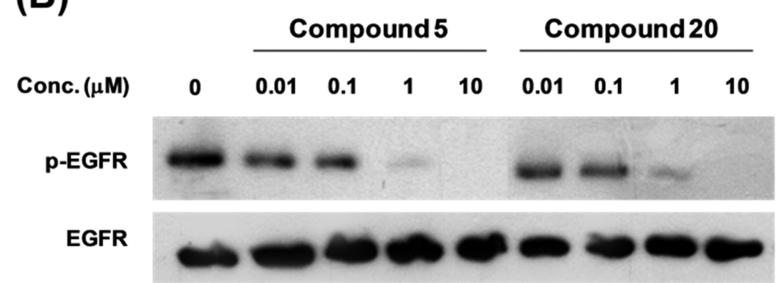

Figure 4. Effect of compounds 5 and 20 on EGFR autophosphorylation in the H1975 cell line harboring the T790M mutation. (A) Percent inhibition of EGFR autophosphorylation for compounds $5(0)$ and $20(\boldsymbol{\square})$ on H1975 cells. Results are reported as the mean \pm $\mathrm{SD}$ of three independent experiments. (B) Representative Western blot analysis for EGFR inhibition by $\mathbf{5}$ and 20. Analysis was done using monoclonal antibodies directed to p-Tyr1068 (see the Experimental Section). Total EGFR is shown as the loading control.

effect of acrylamide released by the 3-aminopropionamide derivative can be enhanced by higher persistence of the prodrug 5, which has detectable intracellular levels in A549 cells $1 \mathrm{~h}$ after incubation (see above).

Evidence for Irreversible Binding to EGFR. Mannich bases are versatile synthetic intermediates used in various transformations to prepare Michael acceptors via elimination of the amino moiety. ${ }^{65}$ As reported in the literature, aryl $\beta$-aminoethyl ketones can irreversibly inhibit enzymes by covalent interaction with cysteine residues ${ }^{38-40}$ after bioconversion to the corresponding $\alpha, \beta$-unsaturated carbonyl compound. The new 3aminopropanamides, characterized by a quinazoline (5-7 and 11-13) or quinoline-3-carbonitrile (15-17 and 19-21) driving portion, showed inhibition of EGFR autophosphorylation in A549 cells after $1 \mathrm{~h}$ of incubation at $1 \mu \mathrm{M}$ concentration, and the effect generally persisted up to $8 \mathrm{~h}$ after removal of the compounds from the reaction medium (Table 1). In principle, the long-lasting effect observed on EGFR autophosphorylation could be ascribed to different phenomena: (i) accumulation of the inhibitor in cells, as previously demonstrated for some reversible quinazolines; ${ }^{66}$ (ii) conversion of the competitive inhibitor into an irreversible one at the active site of the enzyme (mechanism-based inhibition), as described for other $\beta$-aminocarbonyl compounds; ${ }^{38}$ (iii) generation of the corresponding reactive acrylamide, as described for aryl $\beta$-aminoethyl ketones that have potential application as prodrugs of unsaturated ketones. ${ }^{67}$

As previously described, ${ }^{54,66}$ some reversible quinazoline EGFR inhibitors are sequestered in cells generating falsepositive results in the autophosphorylation assay based on the $8 \mathrm{~h}$ washout protocol. As an example, the fully reversible compound 1, which is strongly sequestered in cells, produced $46.4 \% \pm 6.7 \%$ inhibition of EGFR autophosphorylation (A459 cells) at $1 \mu \mathrm{M}$ concentration $8 \mathrm{~h}$ after removal from the medium.
We therefore first tested if the long-lasting inhibition observed for the new 3 -aminopropamides of Table 1 could be explained by their accumulation in cells. The absence of a detectable amount of 5 in A549 cells after the $8 \mathrm{~h}$ period, and the presence of $\mathbf{1}$ in the same conditions, ${ }^{57}$ suggested that $\mathbf{5}$ is not accumulated in the A549 cell line. Moreover, data from fluorescencebased assay for irreversible enzyme inhibition (Figure 2) ruled out direct interaction between the 3-aminopropanamide $\mathbf{5}$ and purified EGFR-TK in the chosen time period. On the other hand, reactivity studies on $\mathbf{5}$ indicated that the compound regenerated significant amounts of the acrylamide 3 only in the presence of cell lysate (Figure 3 ) while it did not under cell-free conditions (Tables 2 and 3 ). The results demonstrate that 5 can act as a prodrug of 3 , releasing the acrylamide fragment in the intracellular environment of A549 cells.

In principle, activation of 3-aminopropanamides to acrylamides in the intracellular environment could be affected by the nature of the heterocyclic nucleus (i.e., quinazoline or quinoline-3-carbonitrile), since a specific enzymatic transformation is likely to occur. However, the similar behavior of quinazolines (A- and B-series) and quinoline-3-carbonitriles (C- and D-series) on EGFR autophosphorylation at $8 \mathrm{~h}$, as well as previous data on the in vivo activity of Mannich bases (see the Introduction), suggests that activation of the $\beta$-aminocarbonyl fragment to a Michael acceptor is a rather general process. In this context, masking the electrophilic warhead may provide some improvements in the pharmacokinetic or pharmacodynamic profile of antiproliferative agents. Although not conclusive evidence of specific advantages, the observation that some 3-aminopropanamide derivatives in the quinazoline and quinoline-3-carbonitrile series showed inhibition potencies on H1975 cell lines close to those of the corresponding acrylamides encourages further evaluation of the biological properties of these compounds.

\section{CONCLUSION}

We report here a new series of EGFR inhibitors containing a 3-aminopropanamide linked to a 4-anilinoquinazoline (5-7 and 11-13) or 4-anilinoquinoline-3-carbonitrile $(15-17$ and 19-21) nucleus. The newly synthesized 3-aminopropanamides proved efficient in inhibiting EGFR-TK activity, showing a long-lasting effect on the enzyme autophosphorylation in A549 lung cancer cells. Notably, several 3-aminopropanamides suppressed proliferation of gefitinib-resistant NSCLC cells (H1975) at significantly lower concentration than 1. Furthermore, compounds 5 and 20 blocked mutated (T790M) EGFRTK activity on the resistant cellular model.

Finally, a combined approach, based on (i) in vitro chemical stability assays, (ii) reactivity studies in the presence of thiol nucleophiles, and (iii) reactivity studies toward EGFR tyrosine kinase and in the presence of cell lysate, showed that 3(dimethylamino)propanamide $\mathbf{5}$ acts as a prodrug, releasing the acrylamide derivative 3 in the intracellular environment, although it is stable in other conditions.

In conclusion, these findings expand the chemical diversity of irreversible inhibitors of EGFR, and similar strategies might be applied to the design of compounds able to form a covalent bond with a peripheral cysteine residue within a biological target.

\section{EXPERIMENTAL SECTION}

Reagents were obtained from commercial suppliers and used without further purification. Solvents were purified and stored according to standard procedures. Anhydrous reactions were conducted under a 
positive pressure of dry $\mathrm{N}_{2}$. Reactions were monitored by TLC, on Kieselgel 60 F 254 (DC-Alufolien, Merck). Final compounds and intermediates were purified by flash chromatography $\left(\mathrm{SiO}_{2} 60,40-\right.$ $63 \mu \mathrm{m}$ ). Microwave reactions were conducted using a CEM Discover synthesis unit (CEM Corp., Matthews, NC). Melting points were not corrected and were determined with a Gallenkamp melting point apparatus. The ${ }^{1} \mathrm{H}$ NMR spectra were recorded on a Bruker $300 \mathrm{MHz}$ Avance or on a Bruker $400 \mathrm{MHz}$ Avance spectrometer; chemical shifts ( $\delta$ scale) are reported in parts per million relative to the central peak of the solvent. ${ }^{1} \mathrm{H}$ NMR spectra are reported in the following order: multiplicity, approximate coupling constant ( $J$ value) in hertz, and number of protons; signals are characterized as s (singlet), $d$ (doublet), $\mathrm{dd}$ (doublet of doublets), $\mathrm{t}$ (triplet), $\mathrm{dt}$ (doublet of triplets), q (quartet), m (multiplet), and br s (broad signal). Mass spectra were recorded using an API $150 \mathrm{EX}$ instrument (AB/SCIEX, Toronto, Canada). Compounds $1,{ }^{68} 3,{ }^{54}$ and $4^{69}$ were synthesized according to literature methods. The final compounds were analyzed on a ThermoQuest (Italia) FlashEA 1112 elemental analyzer for C, H, and N. Analyses were within $\pm 0.4 \%$ of the theoretical values (Supporting Information, Table S3). All tested compounds were $>95 \%$ pure by elemental analysis.

$\mathrm{N}$-(4-(3-Bromoanilino)quinazolin-6-yl)-3-(dimethylamino)propanamide (5). A $33 \%(\mathrm{v} / \mathrm{v})$ solution of dimethylamine in absolute EtOH $(0.8 \mathrm{~mL}, 4.46 \mathrm{mmol})$ was added over $15 \mathrm{~min}$ to a stirred suspension of $\mathrm{N}$-(4-(3-Bromoanilino)quinazolin-6-yl)-3-chloropropanamide (27a) (145 mg, $0.36 \mathrm{mmol})$ and $\mathrm{KI}(42 \mathrm{mg}, 0.25 \mathrm{mmol})$ in absolute $\mathrm{EtOH}(10 \mathrm{~mL})$, and the resulting mixture was refluxed for $8 \mathrm{~h}$. After being cooled to $0{ }^{\circ} \mathrm{C}$, the mixture was basified with $\mathrm{KOH}$ pellets $(0.74 \mathrm{~g})$ and stirred for $1 \mathrm{~h}$ at $0{ }^{\circ} \mathrm{C}$. The solvent was evaporated under reduced pressure, and the solid residue was dissolved with EtOAc and washed with brine. The organic phase was dried, the solvent evaporated, and the residue purified by silica gel chromatography $\left(\mathrm{CH}_{2} \mathrm{Cl}_{2} / \mathrm{MeOH}, 99: 1\right.$ to $\left.70: 30\right)$ to give 5 as a pale yellow solid (86\%): mp (EtOAc/n-hexane) $170-172{ }^{\circ} \mathrm{C}$; MS (atmospheric pressure chemical ionization, APCI) $m / z$ 414.4, 416.4; ${ }^{1} \mathrm{H}$ NMR $\left(\mathrm{CD}_{3} \mathrm{OD}\right.$, $300 \mathrm{MHz}) \delta 2.35(\mathrm{~s}, 6 \mathrm{H}), 2.65(\mathrm{t}, J=6.5 \mathrm{~Hz}, 2 \mathrm{H}), 2.78(\mathrm{t}, J=6.5 \mathrm{~Hz}$ $2 \mathrm{H}), 7.29-7.31(\mathrm{~m}, 2 \mathrm{H}), 7.74(\mathrm{~m}, 3 \mathrm{H}), 8.12(\mathrm{br} \mathrm{s}, 1 \mathrm{H}), 8.53(\mathrm{~s}, 1 \mathrm{H})$, 8.66 (br s, $1 \mathrm{H})$. Anal. $\left(\mathrm{C}_{19} \mathrm{H}_{20} \mathrm{BrN}_{5} \mathrm{O}\right) \mathrm{C}, \mathrm{H}, \mathrm{N}$.

$\mathrm{N}$-(4-(3-Bromoanilino)quinazolin-6-yl)-3-piperidin-1-ylpropanamide (6). 27a was reacted with anhydrous piperidine according to the procedure described for compound $\mathbf{5}$. The product was purified by silica gel chromatography $\left(\mathrm{CH}_{2} \mathrm{Cl}_{2} / \mathrm{MeOH}, 95: 5\right)$ to give 6 as a white solid (78\%): $\mathrm{mp}\left(\mathrm{Et}_{2} \mathrm{O}\right) 184-186{ }^{\circ} \mathrm{C}$; MS (APCI) $m / z 454.1$, 456.2; ${ }^{1} \mathrm{H}$ NMR (DMSO- $\left.d_{6}, 300 \mathrm{MHz}\right) \delta 1.61(\mathrm{~m}, 2 \mathrm{H}), 1.74-1.82$ $(\mathrm{m}, 10 \mathrm{H}), 2.68-2.73(\mathrm{~m}, 2 \mathrm{H}), 7.18-7.32(\mathrm{~m}, 3 \mathrm{H}), 7.67(\mathrm{~d}, J=6.8$ $\mathrm{Hz}, 1 \mathrm{H}), 7.83(\mathrm{~d}, J=8.8 \mathrm{~Hz}, 1 \mathrm{H}), 7.97(\mathrm{~s}, 1 \mathrm{H}), 8.08(\mathrm{~s}, 1 \mathrm{H}), 8.71$ (s, $1 \mathrm{H}), 8.89(\mathrm{~s}, 1 \mathrm{H}), 12.04(\mathrm{~s}, 1 \mathrm{H})$. Anal. $\left(\mathrm{C}_{22} \mathrm{H}_{24} \mathrm{BrN}_{5} \mathrm{O} \cdot{ }^{3} /{ }_{4} \mathrm{H}_{2} \mathrm{O}\right) \mathrm{C}$, $\mathrm{H}, \mathrm{N}$.

$\mathrm{N}$-(4-(3-Bromoanilino)quinazolin-6-yl)-3-morpholinopropanamide (7). 27a was reacted with morpholine according to the procedure described for compound 5 . The product was purified by silica gel chromatography $\left(\mathrm{CH}_{2} \mathrm{Cl}_{2} / \mathrm{MeOH}, 95: 5\right)$ to give 7 as a yellow solid (70\%): $\mathrm{mp}\left(\mathrm{Et}_{2} \mathrm{O} / n\right.$-hexane) $196-198{ }^{\circ} \mathrm{C}$; MS (APCI) $\mathrm{m} / z$ 456.2, 458.4; ${ }^{1} \mathrm{H}$ NMR $\left(\mathrm{CDCl}_{3}, 300 \mathrm{MHz}\right) \delta 2.59-2.77(\mathrm{~m}, 8 \mathrm{H}), 3.89$ $(\mathrm{m}, 4 \mathrm{H}), 7.17-7.25(\mathrm{~m}, 3 \mathrm{H}), 7.62(\mathrm{~d}, J=7.4 \mathrm{~Hz}, 1 \mathrm{H}), 7.76(\mathrm{~d}, J=8.9$ $\mathrm{Hz}, 1 \mathrm{H}), 7.90(\mathrm{~s}, 1 \mathrm{H}), 8.16($ br s, $1 \mathrm{H}), 8.67(\mathrm{~s}, 1 \mathrm{H}), 8.93(\mathrm{~d}, J=1.9$ $\mathrm{Hz}, 1 \mathrm{H}), 11.40(\mathrm{~s}, 1 \mathrm{H})$. Anal. $\left(\mathrm{C}_{21} \mathrm{H}_{22} \mathrm{BrN}_{5} \mathrm{O}_{2} \cdot{ }^{1} /{ }_{3} \mathrm{H}_{2} \mathrm{O}\right) \mathrm{C}, \mathrm{H}, \mathrm{N}$.

$\mathrm{N}$-(4-(3-Bromoanilino)quinazolin-6-yl)-3-(4-methylpiperazin-1-yl)propanamide (8). 27a was reacted with $N$-methylpiperazine according to the procedure described for compound 5. The product was purified by silica gel chromatography $\left(\mathrm{CH}_{2} \mathrm{Cl}_{2} / \mathrm{MeOH}, 95: 5\right)$ to give 8 as a white solid $(77 \%): \mathrm{mp}\left(\mathrm{Et}_{2} \mathrm{O}\right) 196{ }^{\circ} \mathrm{C}$; MS (APCI) $\mathrm{m} / \mathrm{z}$ 469.3, 471.3; ${ }^{1} \mathrm{H}$ NMR $\left(\mathrm{CDCl}_{3}, 300 \mathrm{MHz}\right) \delta 2.33(\mathrm{~s}, 3 \mathrm{H}), 2.42-2.49$ $(\mathrm{m}, 12 \mathrm{H}), 6.94-7.07(\mathrm{~m}, 3 \mathrm{H}), 7.44-7.51(\mathrm{~m}, 2 \mathrm{H}), 7.58(\mathrm{~s}, 1 \mathrm{H})$, $8.50(\mathrm{~s}, 1 \mathrm{H}), 8.68(\mathrm{~m}, 1 \mathrm{H}), 8.88(\mathrm{~s}, 1 \mathrm{H}), 11.55(\mathrm{~s}, 1 \mathrm{H})$. Anal. $\left(\mathrm{C}_{22} \mathrm{H}_{25} \mathrm{BrN}_{6} \mathrm{O} \cdot 1 /{ }_{2} \mathrm{H}_{2} \mathrm{O}\right) \mathrm{C}, \mathrm{H}, \mathrm{N}$.

$\mathrm{N}$-(4-(3-Bromophenylamino)quinazolin-6-yl)-3-(dimethylamino)- $N$-methylpropanamide (9). $N$-(4-((3-Bromophenyl)amino)quinazolin-6-yl)-3-chloro- $N$-methylpropanamide (27b) was reacted with dimethylamine according to the procedure described for compound $\mathbf{5}$.
Silica gel chromatography purification $\left(\mathrm{CH}_{2} \mathrm{Cl}_{2} / \mathrm{MeOH}, 98: 2\right.$ to 90:10) afforded 9 as a white solid (68\%): $\mathrm{mp}\left(\mathrm{CH}_{2} \mathrm{Cl}_{2} / n\right.$-hexane) 169-172 ${ }^{\circ} \mathrm{C}$; MS (APCI) $\mathrm{m} / z$ 430.4, 431.4, 432.4; ${ }^{1} \mathrm{H}$ NMR $\left(\mathrm{CD}_{3} \mathrm{OD}, 300 \mathrm{MHz}\right) \delta 2.14(\mathrm{~s}, 6 \mathrm{H}), 2.39(\mathrm{br} \mathrm{s}, 2 \mathrm{H}), 2.67($ br s, $2 \mathrm{H})$, $3.40(\mathrm{~s}, 3 \mathrm{H}), 7.34(\mathrm{~m}, 2 \mathrm{H}), 7.79(\mathrm{~m}, 1 \mathrm{H}), 7.85(\mathrm{dd}, J=8.6,2.3 \mathrm{~Hz}$, $1 \mathrm{H}), 7.93(\mathrm{~d}, J=8.0 \mathrm{~Hz}, 1 \mathrm{H}), 8.17(\mathrm{~s}, 1 \mathrm{H}), 8.42(\mathrm{~s}, 1 \mathrm{H}), 8.66(\mathrm{~s}, 1 \mathrm{H})$. Anal. $\left(\mathrm{C}_{20} \mathrm{H}_{22} \mathrm{BrN}_{5} \mathrm{O}\right) \mathrm{C}, \mathrm{H}, \mathrm{N}$.

$\mathrm{N}$-(4-(3-Chloro-4-fluoroanilino)-7-ethoxyquinazolin-6-yl)acrylamide (10). Acryloyl chloride $(25 \mu \mathrm{L}, 0.3 \mathrm{mmol})$ in anhydrous THF $(0.5 \mathrm{~mL})$ was added dropwise to a solution of 6-aminoquinazoline $34(100 \mathrm{mg}, 0.3 \mathrm{mmol})$ and $\mathrm{N}, \mathrm{N}$-diisopropylethylamine (DIPEA) $(52 \mu \mathrm{L}, 0.3 \mathrm{mmol})$ in anhydrous DMF $(2.5 \mathrm{~mL})$ at $0{ }^{\circ} \mathrm{C}$. The reaction mixture was stirred for $1 \mathrm{~h}$, then the solvent was removed under reduced pressure, and the residue was purified by silica gel chromatography $\left(\mathrm{CH}_{2} \mathrm{Cl}_{2} / \mathrm{MeOH}, 95: 5\right)$ to afford 10 as a white solid (25\%): $\mathrm{mp}\left(\mathrm{EtOH} / \mathrm{H}_{2} \mathrm{O}\right) 228.5-230{ }^{\circ} \mathrm{C}$; MS (APCI) $\mathrm{m} / z$ 387.3, 389.3; ${ }^{1} \mathrm{H}$ NMR (acetone- $\left.d_{6}, 400 \mathrm{MHz}\right) \delta 1.52(\mathrm{t}, J=6.9 \mathrm{~Hz}, 3 \mathrm{H}), 4.35(\mathrm{q}, J=$ $6.9 \mathrm{~Hz}, 2 \mathrm{H}), 5.83(\mathrm{dd}, J=10.1,1.7 \mathrm{~Hz}, 1 \mathrm{H}), 6.45(\mathrm{dd}, J=16.8,1.7 \mathrm{~Hz}$, $1 \mathrm{H}), 6.70(\mathrm{dd}, J=16.8,10.1 \mathrm{~Hz}, 1 \mathrm{H}), 7.29(\mathrm{~s}, 1 \mathrm{H}), 7.32(\mathrm{t}, J=9.0 \mathrm{~Hz}$, $1 \mathrm{H}$ ), 7.86 (ddd, $J=9.0,4.1,2.8 \mathrm{~Hz}, 1 \mathrm{H}), 8.25$ (dd, $J=6.8,2.6 \mathrm{~Hz}$, $1 \mathrm{H}), 8.57(\mathrm{~s}, 1 \mathrm{H}), 9.04(\mathrm{~s}, 1 \mathrm{H})$. Anal. $\left(\mathrm{C}_{19} \mathrm{H}_{16} \mathrm{ClFN}_{4} \mathrm{O}_{2}\right) \mathrm{C}, \mathrm{H}, \mathrm{N}$.

$\mathrm{N}$-(4-(3-Chloro-4-fluoroanilino)-7-ethoxyquinazolin-6-yl)-3(dimethylamino)propanamide (11). 3-Chloropropanamide 35 was reacted with dimethylamine according to the procedure described for compound 5. The product was purified by silica gel chromatography (AcOEt/MeOH, 99:1 to 85:15) to obtain 11 as a white solid (85\%): $\mathrm{mp}\left(\mathrm{EtOH} / \mathrm{H}_{2} \mathrm{O}\right) 182-183{ }^{\circ} \mathrm{C}$; MS (APCI) $\mathrm{m} / z$ 432.5, 434.3; ${ }^{1} \mathrm{H}$ NMR $\left(\mathrm{CD}_{3} \mathrm{OD}, 300 \mathrm{MHz}\right) \delta 1.54(\mathrm{t}, J=7.0 \mathrm{~Hz}, 3 \mathrm{H}), 2.37(\mathrm{~s}, 6 \mathrm{H})$ $2.69(\mathrm{~m}, 4 \mathrm{H}), 4.26(\mathrm{q}, J=7.0 \mathrm{~Hz}, 2 \mathrm{H}), 7.11(\mathrm{~s}, 1 \mathrm{H}), 7.21(\mathrm{t}, J=$ $9.0 \mathrm{~Hz}, 1 \mathrm{H}), 7.62$ (ddd, $J=9.0,4.1,2.7 \mathrm{~Hz}, 1 \mathrm{H}), 7.95(\mathrm{dd}, J=6.7$, $2.6 \mathrm{~Hz}, 1 \mathrm{H}), 8.41(\mathrm{~s}, 1 \mathrm{H}), 8.83(\mathrm{~s}, 1 \mathrm{H})$. Anal. $\left(\mathrm{C}_{21} \mathrm{H}_{23} \mathrm{ClFN}_{5} \mathrm{O}_{2} \cdot{ }^{2} /{ }_{3} \mathrm{H}_{2} \mathrm{O}\right)$ C, $\mathrm{H}, \mathrm{N}$.

$\mathrm{N}$-(4-(3-Chloro-4-fluoroanilino)-7-ethoxyquinazolin-6-yl)-3piperidin-1-ylpropanamide (12). 3-Chloropropanamide 35 was reacted with anhydrous piperidine according to the procedure described for compound $\mathbf{5}$. The product was purified by silica gel chromatography (AcOEt/MeOH, 99:1 to 93:7) to give $\mathbf{1 2}$ as a white solid (60\%): $\mathrm{mp}\left(\mathrm{EtOH} / \mathrm{H}_{2} \mathrm{O}\right)$ 106.5-108 ${ }^{\circ} \mathrm{C}$; MS (APCI) $\mathrm{m} / \mathrm{z}$ 472.2, 474.2; ${ }^{1} \mathrm{H}$ NMR (DMSO- $\left.d_{6}, 400 \mathrm{MHz}\right) \delta 1.54(\mathrm{t}, J=6.9 \mathrm{~Hz}$, $5 \mathrm{H}), 1.68(4 \mathrm{H}, \mathrm{m}), 2.56(\mathrm{~s}, 4 \mathrm{H}), 2.75(\mathrm{~m}, 4 \mathrm{H}), 4.38(\mathrm{q}, J=6.9 \mathrm{~Hz}$, $2 \mathrm{H}), 7.22(\mathrm{~s}, 1 \mathrm{H}), 7.25(\mathrm{t}, J=8.9 \mathrm{~Hz}, 1 \mathrm{H}), 7.65(\mathrm{ddd}, J=9.0,3.7$, $2.8 \mathrm{~Hz}, 1 \mathrm{H}), 7.99(\mathrm{dd}, J=6.6,2.5 \mathrm{~Hz}, 1 \mathrm{H}), 8.47(\mathrm{~s}, 1 \mathrm{H}), 8.83(\mathrm{~s}, 1 \mathrm{H})$. Anal. $\left(\mathrm{C}_{24} \mathrm{H}_{27} \mathrm{ClFN}_{5} \mathrm{O}_{2} \cdot \mathrm{H}_{2} \mathrm{O}\right) \mathrm{C}, \mathrm{H}, \mathrm{N}$.

$\mathrm{N}$-(4-((3-Chloro-4-fluorophenyl)amino)-7-ethoxyquinazolin6-yl)-3-morpholinopropanamide (13). 3-Chloropropanamide 35 was reacted with morpholine according to the procedure described for compound $\mathbf{5}$. The product was purified by silica gel chromatography (AcOEt/MeOH, 99:1 to 96:4) to obtain 13 as a light yellow solid (96\%): $\mathrm{mp}\left(\mathrm{EtOH} / \mathrm{H}_{2} \mathrm{O}\right) 108-110{ }^{\circ} \mathrm{C}$; $\mathrm{MS}(\mathrm{APCI}) 474.0,476.3{ }^{\circ} \mathrm{C}$; ${ }^{1} \mathrm{H}$ NMR (DMSO- $\left.d_{6}, 400 \mathrm{MHz}\right) \delta 1.54(\mathrm{t}, J=7.0 \mathrm{~Hz}, 3 \mathrm{H}), 2.60(\mathrm{~m}$, $4 \mathrm{H}), 2.74(\mathrm{t}, J=6.0,2 \mathrm{H}), 2.81(\mathrm{t}, J=5.8 \mathrm{~Hz}, 2 \mathrm{H}), 3.77(\mathrm{t}, J=4.6 \mathrm{~Hz}$, $4 \mathrm{H}), 4.37-4.41(\mathrm{~m}, 2 \mathrm{H}), 7.18-7.26(\mathrm{~m}, 2 \mathrm{H}), 7.63-7.65(\mathrm{~m}, 1 \mathrm{H})$, $7.97-7.99(\mathrm{~m}, 1 \mathrm{H}), 8.46(\mathrm{~d}, J=2.9 \mathrm{~Hz}, 1 \mathrm{H}), 8.83(\mathrm{~d}, J=4.7 \mathrm{~Hz}, 1 \mathrm{H})$. Anal. $\left(\mathrm{C}_{23} \mathrm{H}_{25} \mathrm{ClFN}_{5} \mathrm{O}_{3} \cdot{ }^{2} /{ }_{3} \mathrm{H}_{2} \mathrm{O}\right) \mathrm{C}, \mathrm{H}, \mathrm{N}$.

$\mathrm{N}$-(4-(3-Chloro-4-fluoroanilino)-3-cyano-7-ethoxyquinolin6-yl)acrylamide (14). The product was obtained by coupling the amino intermediate 42a with acryloyl chloride as described for compound 10. Silica gel chromatography purification (EtOAc/ $n$-hexane, 60:40) afforded $14(40 \%)$ as a white solid: $\mathrm{mp}\left(\mathrm{EtOH} / \mathrm{H}_{2} \mathrm{O}\right)>$ $230{ }^{\circ} \mathrm{C}$; MS (APCI) $\mathrm{m} / z$ 411.0; ${ }^{1} \mathrm{H}$ NMR (DMSO- $\left.d_{6}, 300 \mathrm{MHz}\right) \delta$ $1.48(\mathrm{t}, J=6.9 \mathrm{~Hz}, 3 \mathrm{H}), 4.33(\mathrm{q}, J=6.9 \mathrm{~Hz}, 2 \mathrm{H}), 5.81(\mathrm{~d}, J=10.7 \mathrm{~Hz}$, $1 \mathrm{H}), 6.29(\mathrm{~d}, J=16.5 \mathrm{~Hz}, 1 \mathrm{H}), 6.77(\mathrm{dd}, J=16.5,9.7 \mathrm{~Hz}, 1 \mathrm{H}), 7.25$ (m, 1H), $7.41(\mathrm{~m}, 3 \mathrm{H}), 8.53(\mathrm{~s}, 1 \mathrm{H}), 8.98(\mathrm{~s}, 1 \mathrm{H}), 9.60(\mathrm{~s}, 1 \mathrm{H}), 9.75$ (br s, $1 \mathrm{H})$. Anal. $\left(\mathrm{C}_{21} \mathrm{H}_{16} \mathrm{ClFN}_{4} \mathrm{O}_{2} \cdot{ }^{1} /{ }_{2} \mathrm{H}_{2} \mathrm{O}\right) \mathrm{C}, \mathrm{H}, \mathrm{N}$.

$\mathrm{N}$-(4-(3-Chloro-4-fluoroanilino)-3-cyano-7-ethoxyquinolin6-yl)-3-(dimethylamino)propanamide (15). 3-Chloropropanamide 43a was reacted with dimethylamine according to the procedure described for compound 5. Silica gel chromatography $\left(\mathrm{CH}_{2} \mathrm{Cl}_{2} /\right.$ $\mathrm{MeOH}, 99: 1$ to $97: 3)$ gave 15 as a light yellow solid (69\%): $\mathrm{mp}(\mathrm{EtOH}) 168-171{ }^{\circ} \mathrm{C}$; ${ }^{1} \mathrm{H}$ NMR (DMSO- $\left.d_{6}, 300 \mathrm{MHz}\right) \delta 1.48$ 
$(\mathrm{t}, J=7.0 \mathrm{~Hz}, 3 \mathrm{H}), 2.29(\mathrm{~s}, 6 \mathrm{H}), 2.57(\mathrm{~m}, 4 \mathrm{H}), 4.32(\mathrm{q}, J=7.0 \mathrm{~Hz}$, $2 \mathrm{H}), 7.19(\mathrm{~m}, 1 \mathrm{H}), 7.40(\mathrm{~m}, 3 \mathrm{H}), 8.54(\mathrm{~s}, 1 \mathrm{H}), 9.06(\mathrm{~s}, 1 \mathrm{H}), 9.68$ (br s, $1 \mathrm{H}), 10.98(\mathrm{~s}, 1 \mathrm{H})$. Anal. $\left(\mathrm{C}_{23} \mathrm{H}_{23} \mathrm{ClFN}_{5} \mathrm{O}_{2} \cdot \mathrm{H}_{2} \mathrm{O}\right) \mathrm{C}, \mathrm{H}, \mathrm{N}$.

$\mathrm{N}$-(4-(3-Chloro-4-fluoroanilino)-3-cyano-7-ethoxyquinolin6-yl)-3-piperidin-1-ylpropanamide (16). 3-Chloropropanamide 43a was reacted with piperidine according to the procedure described for compound 5. Silica gel chromatography $\left(\mathrm{CH}_{2} \mathrm{Cl}_{2} / \mathrm{MeOH}, 96: 4\right)$ gave 16 as a white solid (45\%): mp (EtOH) $180-184{ }^{\circ} \mathrm{C}$; MS (APCI) $m / z$ 496.4, 497.3, 499.4; ${ }^{1} \mathrm{H}$ NMR (DMSO- $\left.d_{6}, 400 \mathrm{MHz}\right) \delta 1.46\left(\mathrm{t}_{\text {, }}\right.$ $J=7.0 \mathrm{~Hz}, 3 \mathrm{H}) ; 1.49(\mathrm{~m}, 2 \mathrm{H}), 1.56(\mathrm{~m}, 4 \mathrm{H}), 2.44(\mathrm{~m}, 4 \mathrm{H}), 2.60(\mathrm{~s}$, $4 \mathrm{H}), 4.39(\mathrm{t}, J=7.0 \mathrm{~Hz}, 2 \mathrm{H}), 7.22(\mathrm{~m}, 1 \mathrm{H}), 7.41(\mathrm{~m}, 3 \mathrm{H}), 8.54$ $(\mathrm{s}, 1 \mathrm{H}), 8.97(\mathrm{~s}, 1 \mathrm{H}), 9.68($ br s, $1 \mathrm{H}), 10.24(\mathrm{~s}, 1 \mathrm{H})$. Anal. $\left(\mathrm{C}_{26} \mathrm{H}_{27} \mathrm{ClFN}_{5} \mathrm{O}_{2} \cdot{ }_{1}{ }_{2} \mathrm{C}_{2} \mathrm{H}_{6} \mathrm{O}\right) \mathrm{C}, \mathrm{H}, \mathrm{N}$.

$\mathrm{N}$-(4-(3-Chloro-4-fluoroanilino)-3-cyano-7-ethoxyquinolin6-yl)-3-morpholinopropanamide (17). 3-Chloropropanamide 43a was reacted with morpholine according to the procedure described for compound 5. Silica gel chromatography $\left(\mathrm{CH}_{2} \mathrm{Cl}_{2} / \mathrm{MeOH}, 98: 2\right)$ afforded 17 as a white solid (52\%): $\mathrm{mp}\left(\mathrm{EtOH} / \mathrm{H}_{2} \mathrm{O}\right) 195-198{ }^{\circ} \mathrm{C}$; MS (APCI) $m / z$ 498.3, 499.2, 500.3; ${ }^{1} \mathrm{H}$ NMR (DMSO- $d_{6}, 400 \mathrm{MHz}$ ) $\delta 1.45(\mathrm{t}, J=7.0 \mathrm{~Hz}, 3 \mathrm{H}), 2.46(\mathrm{~m}, 4 \mathrm{H}), 2.63(\mathrm{~m}, 4 \mathrm{H}), 3.62(\mathrm{t}, J=4.2$ $\mathrm{Hz}, 4 \mathrm{H}), 4.36(\mathrm{q}, J=7.1 \mathrm{~Hz}, 2 \mathrm{H}), 7.20(\mathrm{br} \mathrm{s}, 1 \mathrm{H}), 7.39(\mathrm{~m}, 3 \mathrm{H}), 8.53$ (br s, $1 \mathrm{H}), 8.94(\mathrm{~s}, 1 \mathrm{H}), 9.69(\mathrm{br} s, 1 \mathrm{H}), 9.89(\mathrm{~s}, 1 \mathrm{H})$. Anal. $\left(\mathrm{C}_{25} \mathrm{H}_{25} \mathrm{ClFN}_{5} \mathrm{O}_{3} \cdot 1{ }_{2} \mathrm{C}_{2} \mathrm{H}_{6} \mathrm{O}\right) \mathrm{C}, \mathrm{H}, \mathrm{N}$.

$\mathrm{N}$-(4-(3-Chloro-4-(pyridin-2-ylmethoxy)anilino)-3-cyano-7ethoxyquinolin-6-yl)acrylamide (18). The product was obtained by coupling the amino intermediate $\mathbf{4 2 b}$ with acrylic acid as described for compound 10. Silica gel chromatography purification $\left(\mathrm{CH}_{2} \mathrm{Cl}_{2} /\right.$ $\mathrm{MeOH}, 98: 2)$ gave 18 as a white solid (35\%): $\mathrm{mp}\left(\mathrm{EtOH} / \mathrm{H}_{2} \mathrm{O}\right)>230^{\circ} \mathrm{C}$; MS (APCI) $m / z 500.1 ;{ }^{1} \mathrm{H}$ NMR (DMSO- $\left.d_{6}, 300 \mathrm{MHz}\right) \delta 1.53(\mathrm{t}$, $J=6.9 \mathrm{~Hz}, 3 \mathrm{H}), 4.39(\mathrm{q}, J=6.9 \mathrm{~Hz}, 2 \mathrm{H}), 5.32(\mathrm{~s}, 2 \mathrm{H}) ; 5.79(\mathrm{dd}, J=$ $10.1,1.9 \mathrm{~Hz}, 1 \mathrm{H}), 6.39(\mathrm{dd}, J=16.9,1.9 \mathrm{~Hz}, 1 \mathrm{H}), 6.68(\mathrm{dd}, J=16.9$, $10.1 \mathrm{~Hz}, 1 \mathrm{H}), 7.30(\mathrm{~m}, 3 \mathrm{H}), 7.41(\mathrm{~s}, 1 \mathrm{H}), 7.48(\mathrm{~d}, J=2.3 \mathrm{~Hz}, 1 \mathrm{H})$, $7.68(\mathrm{~d}, J=7.8 \mathrm{~Hz}, 1 \mathrm{H}), 7.87(\mathrm{td}, J=7.8,1.8 \mathrm{~Hz}, 1 \mathrm{H}), 8.50(\mathrm{~s}, 1 \mathrm{H})$, $8.60(\mathrm{~d}, J=4.5 \mathrm{~Hz}, 1 \mathrm{H}), 9.05(\mathrm{~s}, 2 \mathrm{H}), 9.16(\mathrm{~s}, 1 \mathrm{H})$. Anal. $\left(\mathrm{C}_{27} \mathrm{H}_{22} \mathrm{ClN}_{5} \mathrm{O}_{3}\right) \mathrm{C}, \mathrm{H}, \mathrm{N}$.

$\mathrm{N}$-(4-(3-Chloro-4-(pyridin-2-ylmethoxy)anilino)-3-cyano-7ethoxyquinolin-6-yl)-3-(dimethylamino)propanamide (19). 3Chloropropanamide $\mathbf{4 3 b}$ was reacted with dimethylamine according to the procedure described for compound 5. Silica gel chromatography $\left(\mathrm{CH}_{2} \mathrm{Cl}_{2} / \mathrm{MeOH}, 99: 1\right.$ to $\left.90: 10\right)$ gave 19 as a white solid (73\%): $\mathrm{mp}$ (EtOH) $235-237{ }^{\circ} \mathrm{C}$; MS (APCI) $m / z 545.4,547.3,502.7,500.2 ;{ }^{1} \mathrm{H}$ NMR (DMSO- $\left.d_{6}, 300 \mathrm{MHz}\right) \delta 2.29(\mathrm{~s}, 6 \mathrm{H}), 2.54-2.61(\mathrm{~m}, 4 \mathrm{H}), 4.31$ $(\mathrm{q}, J=7.0 \mathrm{~Hz}, 2 \mathrm{H}), 5.28(\mathrm{~s}, 2 \mathrm{H}), 7.17(\mathrm{dd}, J=7.7,1.7 \mathrm{~Hz}, 1 \mathrm{H}), 7.25$ $(\mathrm{d}, J=8.8 \mathrm{~Hz}, 1 \mathrm{H}), 7.38-7.40(\mathrm{~m}, 3 \mathrm{H}), 7.59(\mathrm{~d}, J=7.9 \mathrm{~Hz}, 1 \mathrm{H}), 7.88$ $(\mathrm{dt}, J=7.7,1.7 \mathrm{~Hz}, 1 \mathrm{H}), 8.47(\mathrm{~s}, 1 \mathrm{H}), 8.60(\mathrm{~d}, J=4.0 \mathrm{~Hz}, 1 \mathrm{H}), 9.06$ $(\mathrm{s}, 1 \mathrm{H}), 9.58(\mathrm{br} s, 1 \mathrm{H}), 10.92(\mathrm{br} s, 1 \mathrm{H})$. Anal. $\left(\mathrm{C}_{29} \mathrm{H}_{29} \mathrm{ClN}_{6} \mathrm{O}_{3} \cdot{ }^{1} /{ }_{2} \mathrm{H}_{2} \mathrm{O}\right)$ C, H, N.

$\mathrm{N}$-(4-(3-Chloro-4-(pyridin-2-ylmethoxy)anilino)-3-cyano-7ethoxyquinolin-6-yl)-3-piperidin-1-ylpropanamide (20). 3Chloropropanamide $43 \mathrm{~b}$ was reacted with piperidine according to the procedure described for compound $\mathbf{5}$. Silica gel chromatography $\left(\mathrm{CH}_{2} \mathrm{Cl}_{2} / \mathrm{MeOH}, 97: 3\right.$ to $\left.95: 5\right)$ gave 20 as a light yellow solid (69\%): mp (EtOH) $190-193{ }^{\circ} \mathrm{C}$; MS (APCI) $\mathrm{m} / z$ 585.2, 587.5, 588.5; ${ }^{1} \mathrm{H}$ NMR (DMSO- $\left.d_{6}, 400 \mathrm{MHz}\right) \delta 1.45(\mathrm{t}, J=6.8 \mathrm{~Hz}, 3 \mathrm{H}), 1.50(\mathrm{~m}, 2 \mathrm{H})$, $1.56(\mathrm{~m}, 4 \mathrm{H}), 2.44(\mathrm{~m}, 4 \mathrm{H}), 2.60(\mathrm{~s}, 4 \mathrm{H}), 4.36(\mathrm{q}, J=7.0 \mathrm{~Hz}, 2 \mathrm{H})$, $5.28(\mathrm{~s}, 2 \mathrm{H}), 7.18(\mathrm{~d}, J=8.2 \mathrm{~Hz}, 1 \mathrm{H}), 7.25(\mathrm{~d}, J=8.4 \mathrm{~Hz}, 1 \mathrm{H}), 7.39$ $(\mathrm{m}, 3 \mathrm{H}), 7.58(\mathrm{~d}, J=7.2 \mathrm{~Hz}, 1 \mathrm{H}), 7.88(\mathrm{t}, J=7.3 \mathrm{~Hz}, 1 \mathrm{H}), 8.47$ $(\mathrm{s}, 1 \mathrm{H}), 8.60(\mathrm{~d}, J=4.3 \mathrm{~Hz}, 1 \mathrm{H}), 8.95(\mathrm{~s}, 1 \mathrm{H}), 9.59(\mathrm{~s}, 1 \mathrm{H}), 10.21(\mathrm{~s}$, 1H). Anal. $\left(\mathrm{C}_{32} \mathrm{H}_{33} \mathrm{ClN}_{6} \mathrm{O}_{3} \cdot{ }^{3} /{ }_{2} \mathrm{H}_{2} \mathrm{O}\right) \mathrm{C}, \mathrm{H}, \mathrm{N}$.

$\mathrm{N}$-(4-(3-Chloro-4-(pyridin-2-ylmethoxy)anilino)-3-cyano-7ethoxyquinolin-6-yl)-3-morpholinopropanamide (21). 3-Chloropropanamide $43 \mathrm{~b}$ was reacted with morpholine according to the procedure described for compound 5. Silica gel chromatography $\left(\mathrm{CH}_{2} \mathrm{Cl}_{2} / \mathrm{MeOH}, 99: 1\right.$ to $\left.97: 3\right)$ gave 21 as a light yellow solid $(74 \%)$ : $\mathrm{mp}(\mathrm{EtOH}) 224-228{ }^{\circ} \mathrm{C}$; MS (APCI) $m / z$ 587.3, 589.5; ${ }^{1} \mathrm{H}$ NMR $\left(\mathrm{CDCl}_{3}, 400 \mathrm{MHz}\right) \delta 1.49(\mathrm{t}, J=6.9 \mathrm{~Hz}, 3 \mathrm{H}), 2.55(\mathrm{~m}, 4 \mathrm{H}), 2.67(\mathrm{~m}$, $4 \mathrm{H}), 3.77(\mathrm{~s}, 4 \mathrm{H}), 4.30(\mathrm{q}, J=6.8 \mathrm{~Hz}, 2 \mathrm{H}), 5.19(\mathrm{~s}, 2 \mathrm{H}), 6.72(\mathrm{~s}, 2 \mathrm{H})$, $7.61(\mathrm{~d}, J=7.8 \mathrm{~Hz}, 2 \mathrm{H}), 7.75(\mathrm{t}, J=7.7 \mathrm{~Hz}, 1 \mathrm{H}), 8.16(\mathrm{~s}, 1 \mathrm{H}), 8.32$ (s, $1 \mathrm{H}), 8.58(\mathrm{~d}, J=4.4 \mathrm{~Hz}, 1 \mathrm{H}), 9.19(\mathrm{~s}, 1 \mathrm{H}), 10.08(\mathrm{~s}, 1 \mathrm{H})$. Anal. $\left(\mathrm{C}_{31} \mathrm{H}_{31} \mathrm{ClN}_{6} \mathrm{O}_{4}\right) \mathrm{C}, \mathrm{H}, \mathrm{N}$.
In Vitro Stability and Reactivity Assays. Chemical ( $\mathrm{pH} 7.4, \mathrm{pH}$ 9.0) and rat plasma stability was investigated at $37{ }^{\circ} \mathrm{C}$ according to procedures reported previously. ${ }^{70}$ (See the Supporting Information for details.) The reactivity of $\mathbf{3}$ and $\mathbf{5}$ toward cysteamine, NAC, dithiothreitol (DTT), and reduced GSH was evaluated by adding a freshly prepared thiol solution $(2 \mathrm{mM})$ to $\mathrm{PBS}(\mathrm{pH} 7.4)$ containing the test compound $(1 \mu \mathrm{M})$. Formation of conjugates with LMW thiols after $1 \mathrm{~h}$ of incubation at $37^{\circ} \mathrm{C}$ was measured by HPLC-UV and HPLCESI-MS. The reactivity of compounds $\mathbf{3}$ and $\mathbf{5}$ in A549 cell lysate was tested in the presence of cysteine, to trap thiol-reactive compounds. A549 cells were seeded at 1000000 cells/dish $\left(66 \mathrm{~cm}^{2}\right)$; after 2 days, the cells were lysed mechanically by the freeze/thaw method. Stock solutions $(1 \mathrm{mM})$ of 3 and 5 were prepared in DMSO immediately before use and added to cell lysate at a final concentration of $10 \mu \mathrm{M}$ (equal percentage of DMSO in controls), where $2 \mathrm{mM}$ cysteine had been previously added. Incubations were carried out at $37{ }^{\circ} \mathrm{C}$. At stated time points $(t=0,1$, and $4 \mathrm{~h})$ aliquots were sampled, a double volume of acetonitrile was added, and the resulting solutions were centrifuged $\left(4{ }^{\circ} \mathrm{C}, 10000 \mathrm{~g}, 10 \mathrm{~min}\right)$ and directly analyzed by LCHRMS employing an LTQ-Orbitrap mass analyzer, working in positive ion mode (PIM). (See the Supporting Information for details.)

Determination of Intracellular Concentrations. A549 cells were plated at a 1000000 cells/dish $\left(25 \mathrm{~cm}^{2}\right)$ density. After $24 \mathrm{~h}$, test compounds (3-5) were added to the medium (final concentration $1 \mu \mathrm{M}$, final DMSO concentration $0.1 \%$ ). the cells were incubated for $1 \mathrm{~h}$ at $37^{\circ} \mathrm{C}$ and tested either immediately after or $8 \mathrm{~h}$ after removal of the compound from the extracellular medium by washing the cells three times with $1 \mathrm{~mL}$ aliquots of fresh medium. Compounds were then extracted from the cells with absolute EtOH $\left(1.1 \mathrm{~mL}\right.$ at $\left.4{ }^{\circ} \mathrm{C}\right)$, and the cell extracts were centrifuged $\left(4^{\circ} \mathrm{C}, 10000 \mathrm{~g}, 5 \mathrm{~min}\right)$ and collected. A fixed volume of ethanolic extract was evaporated to dryness, dissolved in HPLC eluent, and injected into the LC-MS system. Calibration curves were built in the concentration range from $5 \mu \mathrm{M}$ to $50 \mathrm{nM}$ for compounds 3-5 (limit of quantification (LOQ) of $50 \mathrm{nM}, \mathrm{LOD}=20 \mathrm{nM})$. Cell proteins were quantified after solubilization in $\mathrm{NaOH}(0.5 \mathrm{~N})\left(2 \mathrm{~mL} / 25 \mathrm{~cm}^{2}\right.$ dish $)$ by the Bradford method. $^{71}$

Analytical Method. A linear gradient elution was set up to evaluate in the same chromatographic run the disappearance of compounds 3 and 5 and the formation of corresponding degradation products. An Agilent 1100 HPLC gradient system (Agilent Technologies, Santa Clara, CA) with an RP-C18 Supelco Discovery (Supelco, Bellefonte, PA), $5 \mu \mathrm{m}, 150 \times 4.6 \mathrm{~mm}$ i.d. column and an $\mathrm{AB} / \mathrm{SCIEX}$ API 150-EX single-quadrupole mass spectrometer equipped with an ESI ion source acquiring in positive ion mode were employed. (See the Supporting Information for details.)

Real-Time Detection of Covalent Bond Formation in Microtiter Plates. The assay was carried out in black 384-well small-volume plates, and fluorescence emission was measured over time by using a multilabel plate reader (Victor, PerkinElmer), as previously described. ${ }^{58}$ EGFR-TK was purchased from Sigma-Aldrich. The sample wells were excited at $390 \mathrm{~nm}$, and the changing emission intensity was monitored at $420 \mathrm{~nm}$. The reaction was monitored immediately after combination of equal volumes $(7 \mu \mathrm{L})$ of EGFR-TK $(0.5 \mu \mathrm{M})$ in buffer $(50 \mathrm{mM}$ Hepes, $200 \mathrm{mM} \mathrm{NaCl}, 0.05 \%$ Triton$\mathrm{X} 100, \mathrm{pH} 7.4)$ containing ATP $(1 \mathrm{mM})$ and inhibitor $(1 \mu \mathrm{M}, 0.2 \%$ DMSO) solution in each well. Data were reported as $\Delta \mathrm{Em}_{420 \mathrm{~nm}}$ calculated as the difference in emission intensity between the samples (inhibitor + EGFR) and controls (inhibitor in buffer solution and EGFR in buffer solution).

Kinase Assay. Evaluation of the effects of compounds on the kinase activity of human EGFR was performed by measuring the phosphorylation of the substrate Ulight-CAGAGAIETDKEYYTVKD (JAK1) using a human recombinant enzyme expressed in insect cells ${ }^{72}$ and the LANCE detection method, ${ }^{73}$ employing the Cerep EGFR kinase assay ${ }^{74}$ as previously described. ${ }^{34}$

Cell Culture. The human NSCLC cell lines A549 and H1975 were cultured as recommended. Medium was supplemented with L-glutamine $(2 \mathrm{mmol} / \mathrm{L})$ and fetal calf serum (FCS) (10\%), and the cells were 
maintained under standard cell culture conditions at $37^{\circ} \mathrm{C}$ in a watersaturated atmosphere of $5 \% \mathrm{CO}_{2}$ in air. The A549 cell line was from the American Type Culture Collection (Manassas, VA), and H1975 was kindly provided by Dr. E. Giovannetti (Department of Medical Oncology, VU University Medical Center, Amsterdam, The Netherlands).

Antibodies and Reagents. Medium was from Euroclone, and fetal bovine serum (FBS) was purchased from Gibco-BRL (Grand Island, NY). Monoclonal anti-EGFR and polyclonal anti-phospho-EGFR (Tyr1068) antibodies were from Cell Signaling Technology (Beverly, MA). Horseradish peroxidase (HRP)-conjugated secondary antibodies were from Pierce. The enhanced chemiluminescence (ECL) system was from Millipore (Millipore, MA). Reagents for electrophoresis and blotting analysis were obtained from, respectively, BIO-RAD Laboratories and Millipore.

Western Blot Analysis. Procedures for protein extraction, solubilization, and protein analysis by 1-D polyacrylamide gel electrophoresis (PAGE) are described elsewhere. ${ }^{75}$ Samples of $40-50 \mu \mathrm{g}$ of proteins from lysates were resolved by $7.5 \%$ sodium dodecyl sulfate (SDS)-PAGE and transferred to poly(vinylidene fluoride) (PVDF) membranes (Millipore). The membranes were then incubated with primary antibody, washed, and then incubated with HRP-antirabbit antibody. Immunoreactive bands were visualized using an enhanced chemiluminescence system.

Autophosphorylation Assay. Inhibition of EGFR autophosphorylation was determined as previously described using specific antiphosphotyrosine and anti total EGFR antibodies by Western blot analysis. ${ }^{34}$

Cell Growth Inhibition. Cell viability was assessed after 3 days of treatment by tetrazolium dye [3-(4,5-dimethylthiazol-2-yl)-2,5-diphenyltetrazolium bromide (MTT), Sigma, Dorset, U.K.] assay as previously described. ${ }^{75}$ Representative results of at least three independent experiments were used for evaluation of dose-response curves, calculated from experimental points using Graph Pad Prism5 software. The concentration that inhibits $50 \%\left(\mathrm{IC}_{50}\right)$ (e.g., the point at which viability is $50 \%$ ) was extrapolated from the dose-response curves.

\section{ASSOCIATED CONTENT}

\section{S Supporting Information}

Experimental procedures for compounds 25-27a,b, 29-35, $41 b, 42 b, 43 a, b$, and 45, combustion analytical data for compounds 3-21, experimental procedures for in vitro stability assays and HPLC-ESI-MS analysis on compounds 3-5, HPLC-MS chromatogram of 5 incubated at $\mathrm{pH} 9.0$ for 24 h, HPLC-MS chromatograms of 3 incubated in the presence of LMW thiols, HR-MS chromatograms of conjugates formed by 3 and $\mathbf{5}$ with cysteine in A549 cell lysate, quantification of the intracellular concentration of compounds 3-5 in A549 cells, and ErbB2 tyrosine kinase inhibition for compounds 3, 5, 19, and 20. This material is available free of charge via the Internet at http://pubs.acs.org.

\section{AUTHOR INFORMATION}

\section{Corresponding Author}

*Phone: +39 0521 905059. Fax: +39 0521 905006. E-mail: marco.mor@unipr.it.

\section{Notes}

The authors declare no competing financial interest.

\section{ACKNOWLEDGMENTS}

Grant support for this work was from the Ministero della Salute (Programma straordinario di ricerca oncologica 2006), Regione Emilia Romagna, AIRC (Associazione Italiana per la Ricerca sul Cancro), Associazione Chiara Tassoni, Parma, and Associazione Davide Rodella, Montichiari BS. We thank Prof. Prisco Mirandola (Department of Anatomy, Pharmacology and
Forensic Medicine at the University of Parma) for support in the fluorescence-based kinase assay.

\section{ABBREVIATIONS USED}

EGFR, epidermal growth factor receptor; erbB2, human epidermal growth factor receptor 2; TK, tyrosine kinase; ATP, adenosine triphosphate; NSCLC, non-small-cell lung cancer; GSH, glutathione; NAC, $N$-acetylcysteine; DTT, dithiothreitol; MTT, 3-(4,5-dimethylthiazol-2-yl)-2,5-diphenyltetrazolium bromide; Red-Al, sodium bis(2-methoxyethoxy)aluminum hydride; DIPEA, N,N-diisopropylethylamine; PBS, phosphate-buffered saline

\section{REFERENCES}

(1) Yarden, Y.; Sliwknowski, M. X. Untangling the ErbB signaling network. Nat. Rev. Mol. Cell. Biol. 2001, 2, 127-137.

(2) Hynes, N. E.; Lane, H. A. ErbB receptors and cancer: the complexity of targeted inhibitors. Nat. Rev. Cancer 2005, 5, 341-354.

(3) Schlessinger, J. Cell signaling by receptor tyrosine kinases. Cell 2000, 103, 211-225.

(4) Olayioye, M. A.; Neve, R. M.; Lane, H. A.; Hynes, N. E. The ErbB signaling network: receptor heterodimerization in development and cancer. EMBO J. 2000, 19, 3159-3167.

(5) Mendelson, J.; Balsega, J. Epidermal growth factor receptor targeting in cancer. Semin. Oncol. 2006, 33, 369-385.

(6) Salomon, D. S.; Brandt, R.; Ciardello, F.; Normanno, N. Epidermal growth factor-related peptides and their receptors in human malignancies. Crit. Rev. Oncol. Hematol. 1995, 19, 183-232.

(7) Teman, S.; Kawaguchi, H.; El-Naggar, A. K.; Jelinek, J.; Tang, H.; Liu, D. D.; Lang, W.; Issa, J. P.; Lee, J. J.; Mao, L. Epidermal growth factor receptor copy number alterations correlate with poor clinical outcome in patients with head and neck squamous cancer. J. Clin. Oncol. 2007, 25, 2164-2170.

(8) Barker, A. J.; Gibson, K. H.; Grundy, W.; Godfrey, A. A.; Barlow, J. J.; Healy, M. P.; Woodburn, J. R.; Ashton, S. E.; Curry, B. J.; Sarlett, L.; Henthorn, L.; Richards, L. Studies leading to the identification of ZD1839 (Iressa): an orally active, selective epidermal growth factor receptor tyrosine kinase inhibitor targeted to the treatment of cancer. Bioorg. Med. Chem. Lett. 2001, 11, 1911-1914.

(9) Moyer, J. D.; Barbacci, E. G.; Iwata, K. K.; Arnold, L.; Boman, B.; Cunningham, A.; Di Orio, C.; Doty, J.; Morin, M. J.; Moyer, M. P.; Neveu, M.; Pollack, V. A.; Pustilnick, L. R.; Reynolds, M. M.; Sloan, D.; Theleman, A.; Miller, P. Induction of apoptosis and cell cycle arrest by CP-358,774, an inhibitor of epidermal growth factor receptor tyrosine kinase. Caner Res. 1997, 57, 4838-4848.

(10) Wood, E. R.; Truesdale, A. T.; McDonald, O. B.; Yuan, D.; Hassell, A.; Dickerson, S. H.; Ellis, B.; Pennisi, C.; Horne, E.; Lackey, K.; Alligood, K. J.; Rusnak, K. D.; Gilmer, T. M.; Shewchuk, L. A unique structure for epidermal growth factor receptor bound to GW572016 (lapatinib): relationships among protein conformation, inhibitor off-rate, and receptor activity in tumor cells. Cancer Res. 2004, 64, 6652-6659.

(11) Lynch, T. J.; Bell, D. W.; Sordella, R.; Gurubhagavatula, S.; Okimoto, R. A.; Brannigan, B. W.; Harris, P. L.; Haserlat, S. M.; Supko, J. G.; Haluska, F. G.; Louis, D. N.; Christiani, D. C.; Settleman, J.; Haber, D. A. Activating mutations in the epidermal growth factor receptor underlying responsiveness of non-small-cell lung cancer to gefitinib. N. Engl. J. Med. 2004, 350, 2129-2139.

(12) Kobayashi, S.; Boggon, T. J.; Dayaram, T.; Jänne, P. A.; Kocher, O.; Meyerson, M.; Johnson, B. E.; Eck, M. J.; Tenen, D. G.; Halmos, B. EGFR mutation and resistance of non-small-cell lung cancer to gefitinib. N. Engl. J. Med. 2005, 352, 786-792.

(13) Pao, W.; Miller, V. A.; Politi, K. A.; Riely, G. J.; Somwar, R.; Zakowski, M. F.; Heelan, R. T.; Kris, M. G.; Varmus, H. E. KRAS mutations and primary resistance of lung adenocarcinomas to gefitinib or erlotinib. PLoS Med. 2005, 2, e17. 
(14) Engelman, J. A.; Jänne, P. A. Mechanisms of acquired resistance to epidermal growth factor receptor tyrosine kinase inhibitors in nonsmall cell lung cancer. Clin. Cancer Res. 2008, 14, 2895-2899.

(15) Yun, C.-H.; Mengwasser, K. E.; Toms, A. V.; Woo, M. S.; Greulich, H.; Wong, K.-K.; Meyerson, M.; Eck, M. J. The T790M mutation in EGFR kinase causes drug resistance by increasing the affinity for ATP. Proc. Natl. Acad. Sci. U.S.A. 2008, 105, 2070-2075.

(16) Fry, D. W.; Bridges, A. J.; Denny, W. A.; Doherty, A.; Greis, K. D.; Hicks, J. L.; Hook, K. E.; Keller, P. R.; Leopold, W. R.; Loo, J. A.; McNamara, D. J.; Nelson, J. M.; Sherwood, V.; Smaill, J. B.; TrumppKallmeyer, S.; Dobrusin, E. M. Specific, irreversible inactivation of the epidermal growth factor receptor and erbB2, by a new class of tyrosine kinase inhibitor. Proc. Natl. Acad. Sci. U.S.A. 1998, 95, 12022-12027.

(17) Blair, J. A.; Rauh, D.; Kung, C.; Yun, C.-H.; Fan, Q.-W.; Rode, H.; Zhang, C.; Eck, M. J.; Weiss, W. A.; Shokat, K. M. Structure-guided development of affinity probes for tyrosine kinases using chemical genetics. Nat. Chem. Biol. 2007, 3, 229-238.

(18) Kwak, E. L.; Sordella, R.; Bell, D. W.; Godin-Heymann, N.; Okimoto, R. A.; Branningan, B. W.; Harria, P. L.; Driscoli, D. R.; Fidias, P.; Lynch, T. J.; Rabindran, S. K.; McGinnis, J. P.; Sharma, S. V.; Isselbacher, K. J.; Settleman, J.; Haber, D. A. Irreversible inhibitors of the EGF receptor may circumvent acquired resistance to gefitinib. Proc. Natl. Acad. Sci. U.S.A. 2005, 102, 7665-7670.

(19) Carter, T. A.; Wodicka, L. M.; Shah, N. P.; Velasco, A. M.; Fabian, M. A.; Treiber, D. K.; Milanov, Z. V.; Atteridge, C. E.; Biggs, V. H.; Edeen, P. T.; Floyd, M.; Ford, J. M.; Grotzfeld, R. M.; Herrgard, S.; Insko, D. E.; Mehta, S. A.; Patel, H. K.; Pao, W.; Sawyers, C. L.; Varmus, H.; Zarrinkar, P. P.; Lockhart, D. J. Inhibition of drugresistant mutants of $\mathrm{ABL}, \mathrm{KIT}$, and EGF receptor kinases. Proc. Natl. Acad. Sci. U.S.A. 2005, 102, 11011-11016.

(20) Godin-Heymann, N.; Ulkus, L.; Brannigan, B. W.; McDermott, U.; Lamb, J.; Maheswaran, S.; Settleman, J.; Haber, D. A. The T790M "gatekeeper" mutation in EGFR mediates resistance to low concentration of an irreversible EGFR inhibitor. Mol. Cancer Ther. 2008, 7, 874-879.

(21) Slichenmyer, W. J.; Elliott, W. L.; Fry, D. W. CI-1033, a pan-erbB tyrosine kinase inhibitor. Semin. Oncol. 2001, 28, 80-85.

(22) Minkovsky, N.; Berezov, A. BIBW-2992, a dual receptor tyrosine kinase inhibitor for the treatment of solid tumours. Curr. Opin. Invest. Drugs 2008, 9, 1336-1346.

(23) Rabindran, S. K.; Discafani, C. M.; Rosfjord, E. C.; Baxter, M.; Floyd, M. B.; Golas, J.; Hallett, W. A.; Johnson, B. D.; Nilakantan, D.; OverBeek, E.; Reich, M. F.; Shen, R.; Shi, X.; Tsou, H. R.; Wang, Y. F.; Wissner, A. Antitumor activity of HKI-272, an orally active, irreversible inhibitor of the Her-2 tyrosine kinase. Cancer Res. 2004, 64, 3958-3965. (24) Singh, J.; Petter, R. C.; Kluge, A. F. Targeted covalent drugs of the kinase family. Curr. Opin. Chem. Biol. 2010, 14, 475-480.

(25) Tsou, H.-R.; Mamuya, N.; Johnson, B. D.; Reich, M. F.; Gruber, B. C.; Ye, F.; Nilakantan, R.; Shen, R.; Discafani, C.; DeBlanc, R.; Davis, R.; Koehn, F. E.; Greenberger, L. M.; Wang, Y.-F.; Wissner, A. 6-Substituted-4-(3-bromophenylamino)quinazolines as putative irreversible inhibitors of the epidermal growth factor receptor (EGFR) and human epidermal growth factor receptor (HER-2) tyrosine kinases with enhanced antitumor activity. J. Med. Chem. 2001, 44, 2719-2734.

(26) Smaill, J. B.; Showalter, H. D. H.; Zhou, H.; Bridges, A. J.; McNamara, D. J.; Fry, D. W.; Nelson, J. M.; Sherwood, V.; Vincent, P. W.; Roberts, B. J.; Elliott, W. L.; Denny, W. A. Tyrosine kinase inhibitors. 18. 6-Substituted 4-anilinoquinazolines and 4-anilinopyrido$[3,4-d]$ pyrimidines as soluble, irreversible inhibitors of the epidermal growth factor receptor. J. Med. Chem. 2001, 44, 429-440.

(27) Mishani, E.; Abourbeh, G.; Jacobson, O.; Dissoki, S.; Daniel, R. B.; Rozen, G.; Shaul, M.; Levitzki, A. High-affinity epidermal growth factor receptor (EGFR) irreversible inhibitors with diminished chemical reactivities as positron emission tomography (PET)-imaging agent candidates of EGFR overexpressing tumors. J. Med. Chem. 2005, 48, 5337-5348.

(28) Carmi, C.; Lodola, A.; Rivara, S.; Vacondio, F.; Cavazzoni, A.; Alfieri, R. R.; Ardizzoni, A.; Petronini, P. G.; Mor, M. Epidermal growth factor receptor irreversible inhibitors: chemical exploration of the cysteine-trap portion. Mini-Rev. Med. Chem. 2011, 11, 1019-1030.

(29) Zhou, W.; Ercan, D.; Chen, L.; Yun, C.-H.; Li, D.; Capelletti, M; Cortot, A. B.; Chierac, L.; Iacob, R. E.; Padera, R.; Engen, J. R.; Wong, K.-K.; Eck, M. J.; Gray, N. S.; Jänne, P. Novel mutant-selective EGFR kinase inhibitors against EGFR T790M. Nature 2009, 462, 1070-1074.

(30) Garuti, L.; Roberti, M.; Bottegoni, G. Irreversible protein kinase inhibitors. Curr. Med. Chem. 2011, 18, 2981-2994.

(31) Jänne, P. A.; von Pawel, J.; Cohen, R. B.; Crino, L.; Butts, C. A.; Olson, S. S.; Eiseman, I. A.; Chiappori, A. A.; Yeap, B. Y.; Lenehan, P. F.; Dasse, K.; Sheeran, M.; Bonomi, P. D. Multicenter, randomized, phase II trial of CI-1033, an irreversible pan-ERBB inhibitor, for previously treated advanced non small-cell lung cancer. J. Clin. Oncol. 2007, 25, 3936-3944.

(32) Besse, B.; Eaton, K. D.; Soria, J. C.; Lynch, T. J.; Miller, V.; Wong, K. K.; Powell, C.; Quinn, S.; Zacharchuk, C.; Sequist, L. V. Neratinib (HKI-272), an irreversible pan-ErbB receptor tyrosine kinase inhibitor: preliminary results of a phase 2 trial in patients with advanced non-small cell lung cancer. Eur. J. Cancer 2008, Suppl. 6, 64.

(33) Leproult, E.; Barluenga, S.; Moras, D.; Wurtz, J. M.; Winssinger, $\mathrm{N}$. Cysteine mapping in conformationally distinct kinase nucleotide binding sites: application to the design of selective covalent inhibitors. J. Med. Chem. 2011, 54, 1347-1355.

(34) Carmi, C.; Cavazzoni, A.; Vezzosi, S.; Bordi, F.; Vacondio, F.; Silva, C.; Rivara, S.; Lodola, A.; Alfieri, R. R.; La Monica, S.; Galetti, M.; Ardizzoni, A.; Petronini, P. G.; Mor, M. Novel irreversible epidermal growth factor receptor inhibitors by chemical modulation of the cysteine-trap portion. J. Med. Chem. 2010, 53, 2038-2050.

(35) Carmi, C.; Cavazzoni, A.; Zuliani, V.; Lodola, A.; Bordi, F.; Plazzi, P. V.; Alfieri, R. R.; Petronini, P. G.; Mor, M. 5-Benzylidenehydantoins as new EGFR inhibitors with antiproliferative activity. Bioorg. Med. Chem. Lett. 2006, 16, 4021-4025.

(36) Zuliani, V.; Carmi, C.; Rivara, M.; Fantini, M.; Lodola, A.; Vacondio, F.; Bordi, F.; Plazzi, P. V.; Cavazzoni, A.; Galetti, M.; Alfieri, R. R.; Petronini, P. G.; Mor, M. 5-Benzylidene-hydantoins: synthesis and antiproliferative activity on A549 lung cancer cell line. Eur. J. Med. Chem. 2009, 44, 3471-3479.

(37) Cavazzoni, A.; Alfieri, R. R.; Carmi, C.; Zuliani, V.; Galetti, M.; Fumarola, C.; Frazzi, R.; Bonelli, M.; Bordi, F.; Lodola, A.; Mor, M.; Petronini, P. G. Dual mechanisms of action of the 5-benzylidenehydantoin UPR1024 on lung cancer cell lines. Mol. Cancer Ther. 2008, 7, 361-370.

(38) Maresso, A. W.; Wu, R.; Kern, J. W.; Zhang, R.; Janik, D.; Misiakas, D. M.; Duban, M.-E.; Joachimiak, A.; Schneewind, O. Activation of inhibitors of sortase triggers irreversible modification of the active site. J. Biol. Chem. 2007, 282, 23129-23139.

(39) Wenzel, N. I.; Chavain, N.; Wang, Y.; Friebolin, W.; Maes, L.; Pradines, B.; Lanzer, M.; Yardley, V.; Brun, R.; Herold-Mende, C.; Biot, C.; Tóth, K.; Davioud-Charvet, E. Antimalarial versus cytotoxic properties of dual drugs derived from 4-aminoquinolines and Mannich bases: interaction with DNA. J. Med. Chem. 2010, 53, 3214-3226.

(40) Hwang, J. Y.; Arnold, L. A.; Zhu, F.; Kosinski, A.; Mangano, T. J.; Setola, V.; Roth, B. L.; Guy, R. K. Improvement of pharmacological properties of irreversible thyroid receptor coactivator binding inhibitors. J. Med. Chem. 2009, 52, 3892-3901.

(41) Brown, G. R.; Bamford, A. M.; Bowyer, J.; James, D. S.; Rankine, N.; Tang, E.; Torr, V.; Culbert, E. J. Naphthyl ketones: a new class of Janus kinase 3 inhibitors. Bioorg. Med. Chem. Lett. 2000, 10, 575-579.

(42) Flynn, G. A.; Lee, S. A.; Faris, M.; Brandt, D. W.; Chakravaty, S. Intracellular kinase inhibitors. PCT Int. Appl. WO2007/136790, 2007.

(43) Traxler, P.; Trinks, U.; Buchdunger, E.; Mett, H.; Meyer, T.; Mueller, M.; Regenass, U.; Roesel, J.; Lydon, N. [(Alkylamino)methyl]acrylophenones: potent and selective inhibitors of the epidermal growth factor receptor protein tyrosine kinase. J. Med. Chem. 1995, 38, 2441-2448.

(44) Neelakantan, S.; Nasim, S.; Guzman, M. L.; Jordan, C. T.; Crooks, P. A. Aminopartenolides as novel anti-leukemic agents: discovery of the NF- $\kappa$ B inhibitor, DMAPT (LC-1). Bioorg. Med. Chem. Lett. 2009, 19, 4346-4349. 
(45) Rewcastle, G. W.; Denny, W. A.; Bridges, A. J.; Zhou, H.; Cody, D. R; McMichael, A.; Fry, D. W. Tyrosine kinase inhibitors: synthesis and structure-activity relationships for 4-[(phenylmethyl)amino]- and 4-[(phenylamino)quinazolines as potent adenosine 5'-triphosphate binding site inhibitors of the tyrosine kinase domain of the epidermal growth factor receptor. J. Med. Chem. 1995, 38, 3482-3487.

(46) Roth, G. A.; Tai, J. J. A new synthesis of aryl substituted quinazolin-4(1H)-ones. J. Heterocycl. Chem. 1996, 33, 2051-2053.

(47) Domarkas, J.; Dudouit, F.; Williams, C.; Qiyu, Q.; Banerjee, R.; Brahimi, F.; Jean-Claude, B. J. The combi-targeting concept: synthesis of stable nitrosoureas designed to inhibit the epidermal growth factor receptor (EGFR). J. Med. Chem. 2006, 49, 3544-3552.

(48) Tang, P. C.; Li, X.; Wang, B.; Wang, J.; Chen, L. 6-Amino quinazoline or 3-cyano quinoline derivatives, preparation methods and pharmaceutical uses thereof. PCT Int. Appl. WO2011/029265, 2011.

(49) Wissner, A.; Fraser, H. L.; Ingalls, C. L.; Dushin, R. G.; Floyd, M. B.; Cheung, K.; Nittoli, T.; Ravi, M. R.; Tan, X.; Loganzo, F. Dual irreversible kinase inhibitors: quinazoline-based inhibitors incorporating two independent reactive centers with each targeting different cysteine residues in the kinase domains of EGFR and VEGFR-2. Bioorg. Med. Chem. 2007, 15, 3635-3648.

(50) Tsou, H. R.; Overbeek-Klumpers, E. G.; Hallett, W. A.; Reich, M. F.; Floyd, M. B.; Johnson, B. D.; Michalak, R. S.; Nilakantan, R; Discafani, C.; Golas, J.; Rabindran, S. K.; Shen, R.; Shi, X.; Wang, Y.-F.; Upeslacis, J.; Wissner, A. Optimization of 6,7-disubstituted-4(arylamino)quinoline-3-carbonitriles as orally active, irreversible inhibitors of human epidermal growth factor receptor-2 kinase activity. J. Med. Chem. 2005, 48, 1107-1131.

(51) Wissner, A.; Overbeek, E.; Reich, M. F.; Floyd, M. B.; Johnson, B. D.; Mamuya, N.; Rosfjord, E. C.; Discafani, C.; Davis, R.; Shi, X.; Rabindran, S. K.; Gruber, B. C.; Ye, F.; Hallett, W. A.; Nilakantan, R.; Shen, R.; Wang, Y.-F.; Greenberger, L. M.; Tsou, H.-R. Synthesis and structure-activity relationships of 6,7-disubstituted 4-anilinoquinoline3 -carbonitriles. The design of an orally active, irreversible inhibitor of the tyrosine kinase activity of the epidermal growth factor receptor (EGFR) and the human epidermal growth factor receptor-2 (HER-2). J. Med. Chem. 2003, 46, 49-63.

(52) Chew, W.; Cheal, G. K.; Lunetta, J. F. Methods of synthesizing substituted 3-cyanoquinolines and intermediates thereof. PCT Int. Appl. WO2006/127207, 2006.

(53) Barlaam, B. C.; Ducray, R.; Kettle, J. G. Pyrazolopyrimidine compounds as antitumor agents. PCT Int. Appl. WO2006/064196, 2006.

(54) Smaill, J. B.; Palmer, B. D.; Rewcastle, G. W.; Denny, V. A.; McNamara, D. J.; Dobrusin, E. M.; Bridges, A. J.; Zhou, H.; Showalter, H. D. H.; Winters, R. T.; Leopold, V. R.; Fry, D. V.; Nelson, J. M.; Slintak, V.; Elliot, V. L.; Roberts, B. J.; Vincent, P. W.; Patmore, S. J. Tyrosine kinase inhibitors. 15. 4-(Phenylamino)quinazoline and 4(phenylamino)pyrido[d]pyrimidine acrylamides as irreversible inhibitors of the ATP binding site of the epidermal growth factor receptor. J. Med. Chem. 1999, 42, 1803-1815.

(55) Böhme, A.; Thaens, D.; Paschke, A.; Schüürmann, G. Kinetic glutathione chemoassay to quantify thiol reactivity of organic electrophiles: application to alpha,beta-unsaturated ketones, acrylates, and propiolates. Chem. Res. Toxicol. 2009, 22, 742-750.

(56) Oballa, R. M; Truchon, J. F; Bayly, C. I.; Chauret, N.; Day, S.; Crane, S.; Berthelette, C. A generally applicable method for assessing the electrophilicity and reactivity of diverse nitrile-containing compounds. Bioorg. Med. Chem. Lett. 2007, 17, 998-1002.

(57) Galetti, M.; Alfieri, R. R.; Cavazzoni, A.; La Monica, S.; Bonelli, M.; Fumarola, C.; Mozzoni, P.; De Palma, G.; Andreoli, R.; Mutti, A.; Mor, M.; Tiseo, M.; Ardizzoni, A.; Petronini, P. G. Functional characterization of gefitinib uptake in non-small cell lung cancer cell lines. Biochem. Pharmacol. 2010, 80, 179-187.

(58) Külter, S.; Simard, J. R.; Rode, H. B.; Grütter, C.; Pawar, V.; Raaijmarkers, H. C. A.; Barf, T. A.; Rabiller, M.; van Otterlo, W. A. L.; Rauh, D. Characterization of irreversible kinase inhibitors by direct detecting covalent bond formation: a tool for dissecting kinase drug resistance. ChemBioChem 2010, 11, 2557-2566.
(59) Sos, M. L.; Rode, H. B.; Heynck, S.; Peifer, M.; Fischer, F.; Klüter, S.; Pawar, V. G.; Reuter, C.; Heuckmann, J. M.; Weiss, J.; Ruddigkeit, L.; Rabiller, M.; Koker, M.; Simard, J. R.; Getlik, M.; Yuza, Y.; Chen, T. H.; Greulich, H.; Thomas, R. K.; Rauh, D. Chemogenomic profiling provides insights into the limited activity of irreversible EGFR inhibitors in tumor cells expressing the T790M EGFR resistance mutation. Cancer Res. 2010, 70, 868-874.

(60) Prendergast, F. G.; Meyer, M.; Carlson, G. L.; Iida, S.; Potter, D. Synthesis, spectral properties, and use of 6-acryloyl-2-dimethylaminonaphthalene (Acrylodan). A thiol-selective, polarity-sensitive fluorescent probe. J. Biol. Chem. 1983, 258, 7541-7544.

(61) Weber, G.; Farris, F. J. Synthesis and spectral properties of a hydrophobic fluorescent probe: 6-propionyl-2-(dimethylamino)naphthalene. Biochemistry 1979, 18, 3075-3078.

(62) de Silva, A. P.; Gunaratne, H. Q. N.; Gunnlaugsson, T.; Huxley, A. J. M.; McCoy, C. P.; Rademacher, J. T.; Rice, T. E. Signaling recognition events with fluorescent sensors and switches. Chem. Rev. 1997, 97, 1515-1566.

(63) de Silva, A. P.; Gunaratne, H. Q. N.; Gunnlaugsson, T. Fluorescent PET (photoinducer electron tranfer) reagents for thiols. Tetrahedron Lett. 1998, 39, 5077-5080.

(64) Rauh, D.; Simard, J. R.; Getlik, M. Fluorescently or spin-labeled kinases for rapid screening and identification of novel kinase inhibitor scaffolds, and drug discovery uses. PCT Int. Appl. WO2010009886, 2010.

(65) Arend, M.; Westermann, B.; Risch, N. Modern variants of the Mannich reaction. Angew. Chem., Int. Ed. 1998, 37, 1044-1070.

(66) Bridges, A. J.; Zhou, H.; Cody, D. R.; Rewcastle, G. W.; McMichael, A.; Showalter, H. D. H.; Fry, D. W.; Kraker, A. J.; Denny, W. A. Tyrosine kinase inhibitors. 8. An unusually steep structureactivity relationship for analogues of 4-(3-bromoanilino)-6,7-dimethoxyquinazoline (PD 153035), a potent inhibitor of the epidermal growth factor receptor. J. Med. Chem. 1996, 39, 267-276.

(67) Simplício, A. L.; Clancy, J. M.; Gilmer, J. F. Beta-aminoketones as prodrugs with $\mathrm{pH}$-controlled activation. Int. J. Pharm. 2007, 336, 208-214.

(68) Gilday, J. P.; David, M. Process for the preparation of 4-(3'chloro-4'-fluoroanilino)-7-methoxy-6-(3-morpholinopropoxy)quinazoline. PCT Int. Appl. WO2004/024703, 2004.

(69) Rewcastle, G. W.; Denny, W. A.; Bridges, A. J.; Zhou, H.; Cody, D. R.; McMichael, A.; Fry, D. W. Tyrosine kinase inhibitors: synthesis and structure-activity relationships for 4-[(phenylmethyl)amino]- and 4 -[(phenylamino)quinazolines as potent adenosine 5 'triphosphate binding site inhibitors of the tyrosine kinase domain of the epidermal growth factor receptor. J. Med. Chem. 1995, 38, 3482-3487.

(70) Vacondio, F.; Silva, C.; Lodola, A.; Carmi, C.; Rivara, S.; Duranti, A.; Tontini, A.; Sanchini, S.; Clapper, J. R.; Piomelli, D.; Tarzia, G.; Mor, M. Biphenyl-3-yl alkylcarbamates as fatty acid amide hydrolase (FAAH) inhibitors: steric effects of $N$-alkyl chain on rat plasma and liver stability. Eur. J. Med. Chem. 2011, 46, 4466-4473.

(71) Bradford, M. M. A rapid and sensitive method for the quantitation of microgram quantities of protein utilizing the principle of protein-dye binding. Anal. Biochem. 1976, 72, 248-254.

(72) Weber, W.; Bertics, P. J.; Gill, G. N. Immunoaffinity purification of the epidermal growth factor receptor. Stoichiometry of binding and kinetics of self-phosphorylation. J. Biol. Chem. 1984, 259, 14631-14636.

(73) Olive, D. M. Quantitative methods for the analysis of protein phosphorylation in drug development. Expert Rev. Proteomics 2004, 1, 327-341.

(74) CEREP - Catalog online. www.cerep.fr/cerep/users/pages/ catalog/assay/catalog.asp (accessed 2011).

(75) Cavazzoni, A.; Petronini, P. G.; Galetti, M.; Roz, L.; Andriani, F.; Carbognani, P.; Rusca, M.; Fumarola, C.; Alfieri, R.; Sozzi, G. Dosedependent effect of FHIT-inducible expression in Calu-1 lung cancer cell line. Oncogene 2004, 23, 8439-8446. 